\title{
No.3
}

Special Report

COVID-19
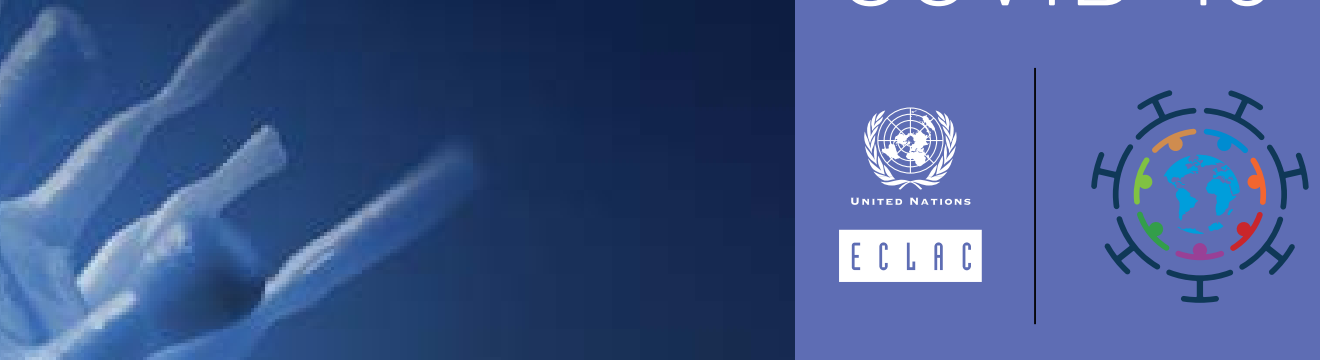

COVID-19

12 May 2020

\section{The social challenge in times of COVID-19}

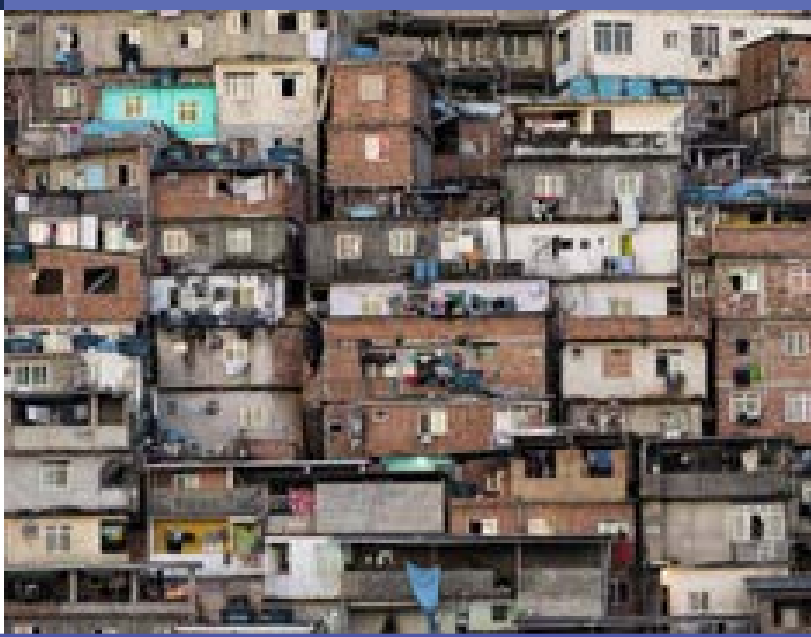

A. Poverty, extreme poverty and inequality will increase in all countries of the region

- The coronavirus disease (COVID-19) pandemic has severe health effects and serious implications for economic growth and social development. It has arrived in Latin America and the Caribbean in a context of low growth -as analysed in the previous special reports on the subject (ECLAC, 2020a and 2020b) - and, above all, of marked inequality and vulnerability, with growing poverty and extreme poverty, weakening of social cohesion and expressions of social discontent.

- Quarantines and physical distancing measures, which are needed to stop the rapid spread of the coronavirus and save lives, are leading to job losses (11.6 million more unemployed in 2020, compared to 2019) and reducing personal and household labour income. The loss of income is primarily affecting the broad strata of the population that are living in or vulnerable to poverty, and people working in activities that are more exposed to layoffs and pay cuts and, in general, those in precarious employment.

- Labour markets in the region are often precarious: there is a high proportion of informal employment $(53.1 \%$ in 2016, according to the International Labour Organization (ILO, 2018)). In 2018, just 47.4\% of the employed were contributing to pension systems and over $20 \%$ of them were living in poverty. Women, girls, indigenous people, Afrodescendants and migrants are all overrepresented among informal workers.

\section{Trends in poverty and extreme poverty}

- Based on the 5.3\% drop in GDP and the 3.4 percentage point increase in unemployment projected by the Economic Commission for Latin America and the Caribbean (ECLAC) in its COVID-19 Special Report, No. 2, in $\mathbf{2 0 2 0}$ poverty in Latin America may rise by at least 4.4 percentage points (28.7 million more people) compared to the prior year, bringing the total number of people living in poverty to

\section{Contents}

A. Poverty, extreme poverty and inequality will increase in all countries

of the region.....

B. Groups particularly vulnerable to the socioeconomic crisis.....

C. Emergency measures and strengthening of existing social protection measures .........7

D. A basic income to meet needs and support consumption .

E. The challenge is to strengthen the welfare State to avoid another lost decade ................ 18

Bibliography ....................................................... 20

Annex. .21 
214.7 million (34.7\% of the region's population) (ECLAC, 2020). Among these people, extreme poverty is likely to increase by 2.6 percentage points (15.9 million additional people), affecting a total of 83.4 million.

- This increase in poverty and extreme poverty seriously undermines the possibility of ending poverty in all its forms everywhere by 2030 (Sustainable Development Goal 1) and to a wider extent the possibility of achieving all the targets relating to the social dimension of the 2030 Agenda for Sustainable Development.

- The impact of the pandemic on GDP and employment varies from country to country, meaning that the projected increases in poverty and extreme poverty also vary. Given the uncertainty over the current situation and how it will evolve, table 1 shows three scenarios (low, medium and high) for poverty and extreme poverty in 17 countries of the region. In the medium scenario, poverty would increase by 4.4 percentage points; in the low scenario, by 3.4 percentage points; and in the high scenario, by 5.5 percentage points.

Table 1 | Latin America (17 countries): projected population living in extreme poverty and poverty in 2020, not including the impacts of policies to mitigate the impacts of the pandemic

(Percentages)

\begin{tabular}{|c|c|c|c|c|c|c|c|c|}
\hline \multirow{3}{*}{ Country } & \multicolumn{4}{|c|}{ Extreme poverty } & \multicolumn{4}{|c|}{ Poverty } \\
\hline & \multirow{2}{*}{$\begin{array}{l}2019^{a} \\
\text { Level }\end{array}$} & \multicolumn{3}{|c|}{$2020^{b}$} & \multirow{2}{*}{$\begin{array}{l}\text { 2019a } \\
\text { Level }\end{array}$} & \multicolumn{3}{|c|}{$2020^{b}$} \\
\hline & & $\begin{array}{l}\text { Low } \\
\text { scenario }\end{array}$ & $\begin{array}{l}\text { Medium } \\
\text { scenario }\end{array}$ & $\begin{array}{l}\text { High } \\
\text { scenario }\end{array}$ & & $\begin{array}{l}\text { Low } \\
\text { scenario }\end{array}$ & $\begin{array}{l}\text { Medium } \\
\text { scenario }\end{array}$ & $\begin{array}{l}\text { High } \\
\text { scenario }\end{array}$ \\
\hline Argentina $^{\mathrm{C}}$ & 3.8 & 5.1 & 5.5 & 6.3 & 26.7 & 32.5 & 33.6 & 35.3 \\
\hline $\begin{array}{l}\text { Bolivia } \\
\text { (Plurinational State of) }\end{array}$ & 14.3 & 15.4 & 16.0 & 16.7 & 32.3 & 33.6 & 34.4 & 35.5 \\
\hline Brazil & 5.4 & 6.9 & 7.4 & 7.9 & 19.4 & 23.0 & 24.3 & 25.4 \\
\hline Chile & 1.4 & 2.1 & 2.3 & 2.6 & 9.8 & 11.9 & 12.7 & 13.7 \\
\hline Colombia & 10.3 & 11.3 & 12.0 & 12.7 & 29.0 & 30.4 & 31.5 & 32.5 \\
\hline Costa Rica & 4.0 & 4.7 & 4.9 & 5.3 & 16.0 & 17.7 & 18.4 & 19.1 \\
\hline Dominican Republic & 4.5 & 4.6 & 4.9 & 5.3 & 20.3 & 20.7 & 21.1 & 21.7 \\
\hline Ecuador & 7.6 & 9.9 & 10.7 & 11.6 & 25.7 & 30.0 & 30.8 & 31.9 \\
\hline El Salvador & 7.4 & 8.5 & 9.0 & 9.6 & 33.7 & 35.4 & 36.4 & 37.3 \\
\hline Guatemala & 19.8 & 21.2 & 21.4 & 21.8 & 48.6 & 50.3 & 50.5 & 50.9 \\
\hline Honduras & 18.7 & 19.5 & 19.8 & 20.5 & 54.8 & 56.3 & 57.1 & 57.8 \\
\hline Mexico & 11.1 & 14.9 & 15.9 & 17.1 & 41.9 & 46.7 & 47.8 & 48.9 \\
\hline Nicaragua & 18.0 & 20.7 & 21.3 & 22.2 & 47.1 & 50.6 & 51.6 & 52.7 \\
\hline Panama & 6.2 & 6.4 & 6.6 & 6.8 & 14.2 & 14.5 & 14.9 & 15.6 \\
\hline Paraguay & 6.2 & 6.3 & 6.5 & 6.9 & 19.4 & 19.8 & 20.3 & 21.1 \\
\hline Peru & 3.7 & 4.6 & 4.8 & 5.1 & 16.5 & 18.5 & 19.1 & 20.1 \\
\hline Uruguay & 0.1 & 0.2 & 0.3 & 0.4 & 2.9 & 4.2 & 4.8 & 5.7 \\
\hline Latin America $^{\mathrm{d}}$ & 11.0 & 13.0 & 13.5 & 14.2 & 30.3 & 33.7 & 34.7 & 35.8 \\
\hline
\end{tabular}

Source: Economic Commission for Latin America and the Caribbean (ECLAC), on the basis of the Household Survey Data Bank (BADEHOG).

a Projections.

b Preliminary projections based on assumed impact on employment and labour income for the different production sectors. The three scenarios are differentiated according to whether the change in average household income is less than (low scenario), equal to (medium scenario) or greater than (high scenario) the change in GDP.

Data for Argentina include only urban areas.

The 17 countries included in the table plus the Bolivarian Republic of Venezuela.

- Four conclusions may be drawn from this information:

(i) In all scenarios, poverty and extreme poverty will increase in all countries.

(ii) In the high scenario, the largest increases in extreme poverty are likely to occur in Mexico, Nicaragua and Ecuador.

(iii) Also in the high scenario, poverty in general will increase especially in Argentina, Mexico, Ecuador and Brazil.

(iv) This exercise exposes the particular vulnerability of the region's three largest economies. 
- The impact described thus far only takes into account the consequences of the pandemic in terms of the labour market and the accompanying loss of income, without considering the effects of policy measures implemented to reduce the social and economic impacts of the pandemic. An additional decline in remittances from family members who have migrated would sharpen poverty among recipients of remittances in senders' countries of origin (see figure 1). This is in fact likely to occur, given the severe impact of COVID-19 in the region and in countries outside the region that are destinations for Latin American and Caribbean migrants, such as the United States and Spain.

Figure 1 | Latin America (13 countries): poverty rate with and without remittances, for households receiving remittances, national totals, around 2017

(Percentages)

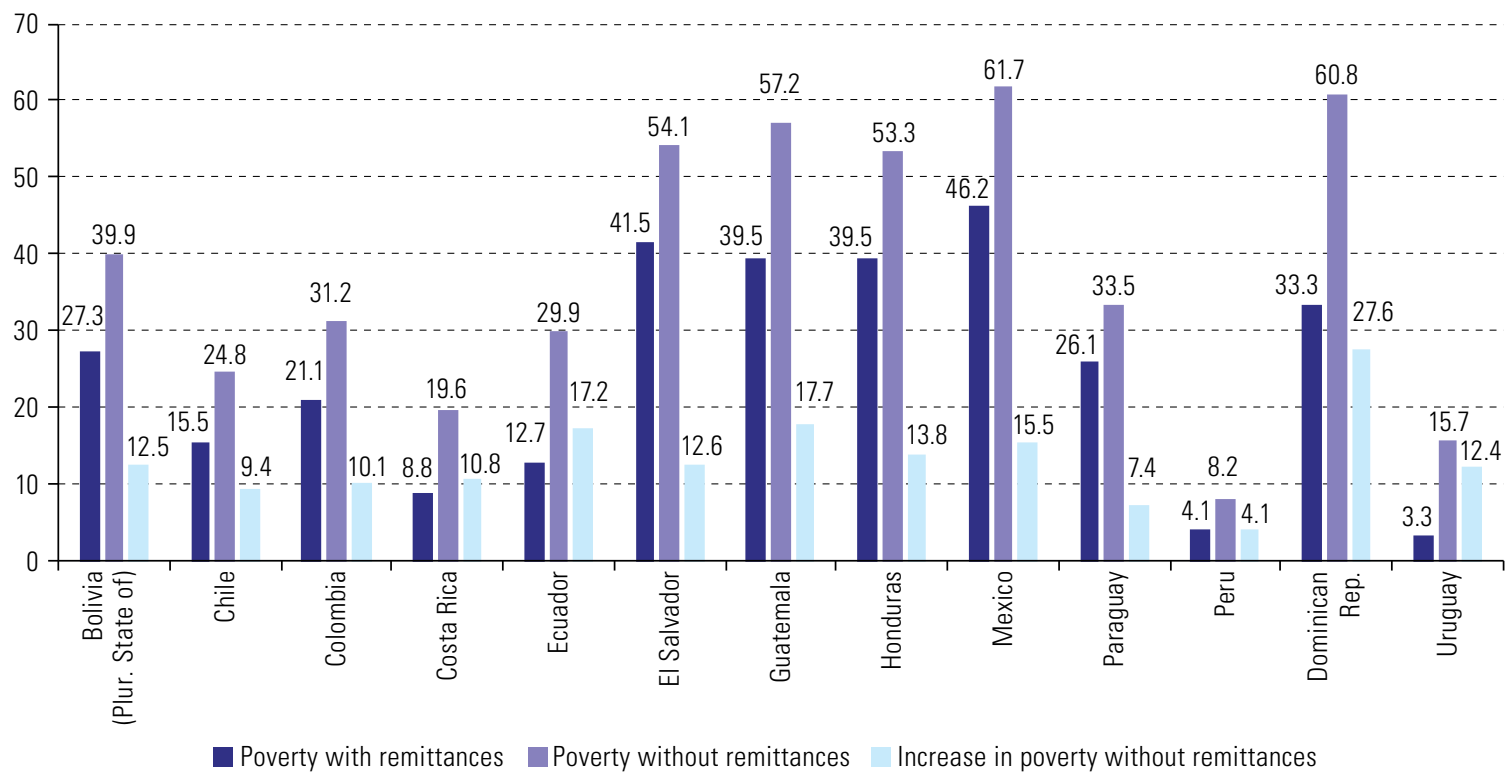

Source:Economic Commission for Latin America and the Caribbean (ECLAC), Social Panorama of Latin America, 2019 (LC/PUB.2019/22-P/Rev.1), Santiago.

- In line with poverty and extreme poverty, inequality is also set to rise in all the region's countries. ECLAC projects increases in the Gini coefficient of between $\mathbf{0 . 5 \%}$ and $\mathbf{6 . 0} \%$. Once again, the worst results are expected in the region's largest economies (see table 2). This is a reversal from the results of the region's efforts in the 2000s, when for the first time in its history inequality began to fall and progress towards equality was shown to have highly positive impacts on the fight against poverty.

Table 2 | Latin America (17 countries): projected change in Gini coefficient in 2020, not including the impacts of policies to mitigate the impacts of the pandemic

\begin{tabular}{ll}
\hline Between $\mathbf{0 . 5} \%$ and $\mathbf{1 . 4 \%}$ & Dominican Republic \\
& Guatemala \\
& Honduras \\
& Panama \\
& Paraguay \\
\hline Between $\mathbf{1 . 5} \%$ and $\mathbf{2 . 9} \%$ & Bolivia (Plurinational State of) \\
& Chile \\
& Colombia \\
& Costa Rica \\
& El Salvador \\
& Nicaragua \\
Peru \\
\hline $\mathbf{3 . 0 \%}$ or more & Argentina \\
Brazil \\
Ecuador \\
Mexico \\
Uruguay \\
\hline
\end{tabular}

Source: Economic Commission for Latin America and the Caribbean (ECLAC), on the basis of the Household Survey Data Bank (BADEHOG). 
- In this scenario of greater poverty and inequality, large sections of the region's population are living in chronic financial insecurity and are highly vulnerable to loss of labour income. In 2019, $77 \%$ of the region's population (470 million people) were in the low or lower-middle income strata, with per capita income up to three times the poverty line (see figure 2). This population did not have sufficient savings to weather a crisis. In 2017, just $31.8 \%$ of the economically active population living in households in the low and lower-middle income strata were affiliated or contributing to pension systems.

- Given the projected fall in regional GDP $(5.3 \%)$ and the rise in unemployment caused by the repercussions of the pandemic, ECLAC estimates that around $10 \%$ of the people who were living in non-extreme poverty in $\mathbf{2 0 1 9}$ (11.8 million people) will see their economic situation deteriorate and will slip into extreme poverty (see figure 2). Similarly, 15\% of those in the low-income non-poor strata (between 1 and 1.8 poverty lines per capita) are expected to fall into non-extreme poverty (20.8 million people) or extreme poverty (3 million people).

Figure 2 | Latin America (18 countries):a population size and trends by per capita income strata, 2019 and 2020 (Millions of persons)

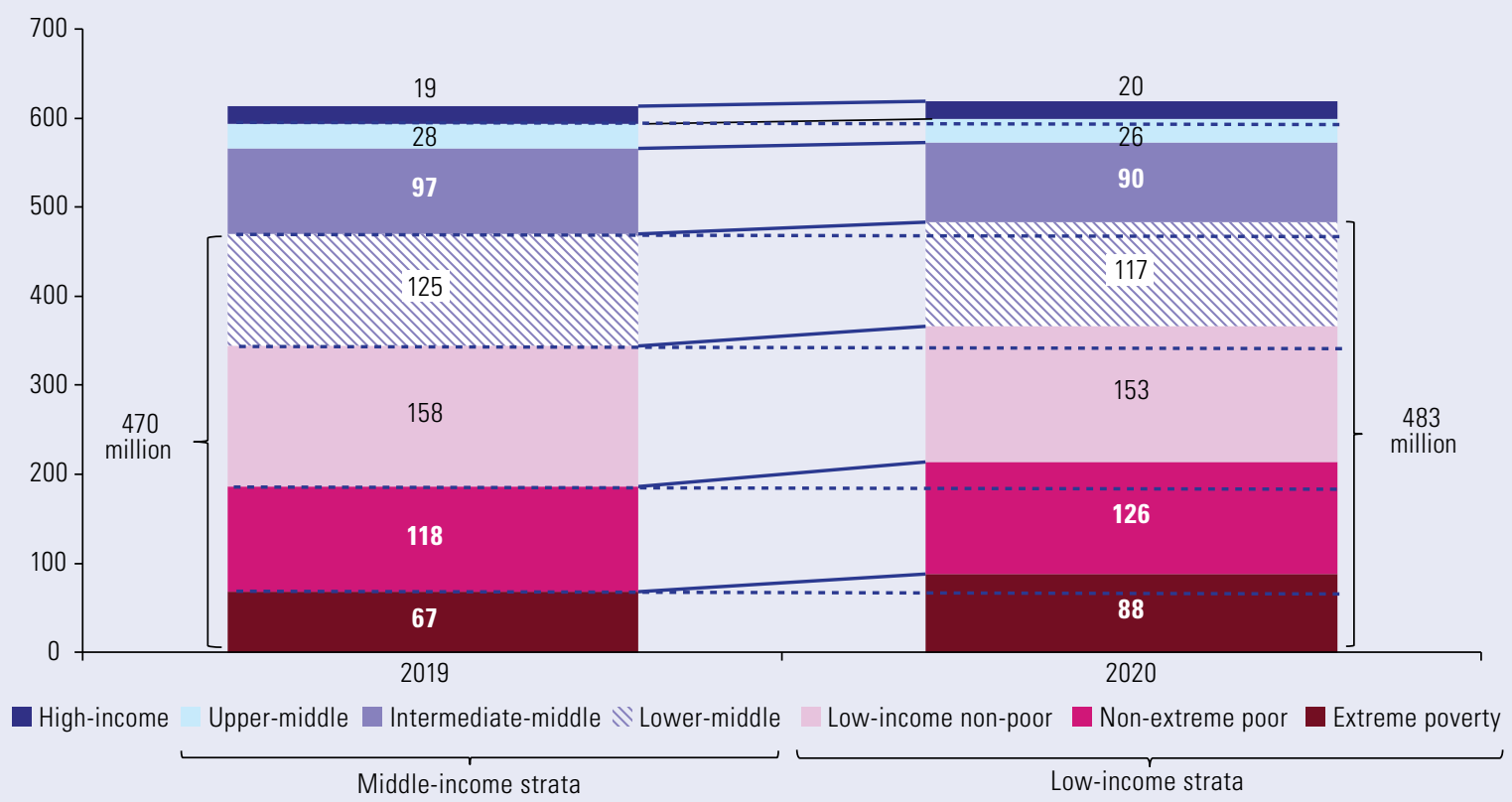

Source: Economic Commission for Latin America and the Caribbean (ECLAC), on the basis of the Household Survey Data Bank (BADEHOG).

a Argentina, Bolivarian Republic of Venezuela, Brazil, Chile, Colombia, Costa Rica, Dominican Republic, Ecuador, El Salvador, Guatemala, Honduras, Mexico, Nicaragua, Panama, Paraguay, Peru, Plurinational State of Bolivia and Uruguay. Data for 2019 are projections based on a 5.3\% drop in GDP and a 3.4 percentage point increase in unemployment.

b Thresholds for per capita income of the strata: "extremely poor" refers to income below one extreme poverty line; "non-extreme poor", from one extreme poverty line to less than one poverty line; "low-income non-poor", from 1 poverty line to less than 1.8 poverty lines; "lower-middle", from 1.8 to 3 poverty lines; "intermediate-middle", more than 3 poverty lines, up to 6 poverty lines; "upper-middle", more than 6 poverty lines and up to 10 poverty lines; and " high ", above 10 poverty lines.

- The situation of those in the middle strata is also likely to deteriorate heavily, although the impact — downward economic mobility between strata - eases higher up the social ladder. Within this group, the lower-middle strata will be most affected. The financial situation of at least $15 \%$ of the lower-middle strata will deteriorate: with 16.7 million moving into low-income strata, but still out of poverty, while 2.5 million will be left in poverty, mainly non-extreme poverty. The middle strata are likely to suffer less deterioration, with only $11 \%$ (10.7 million) slipping down to lower strata, and most (9.1 million) remaining in the lower-middle strata.

- The upper-middle and high-income strata will be the least affected, with economic deterioration pushing them down the stratum immediately below. However, a small proportion of people in these strata may fall —at least temporarily - into poverty or extreme poverty, depending on the decline in their current income.

- People in the upper-middle and high-income sectors may resort to selling assets to sustain their living conditions, albeit in the short term. However, a significant proportion of households (mainly further down the social ladder) maintain their living standards through borrowing. A significant fall in their income could lead to debt distress and subsequent loss of assets. 


\section{B. Groups particularly vulnerable to the socioeconomic crisis}

- The pandemic has a discriminating impact on various population groups and their response capacity. The impossibility of working from home, overcrowded conditions and lack of access to water and sanitation increase the risk of infection of people living in poverty and in vulnerability. Also, their risk of death is greater because of the higher incidence of pre-existing health conditions such as lung disease, cardiovascular disease and diabetes, and because they lack adequate access to medical care.

- The different socioeconomic impacts reflect the social inequality matrix in the region, which is built around the axes of socioeconomic stratum or social class, gender, life-cycle stage, ethnicity or race and territory, along with other factors such as disability, migratory status and homelessness. These inequalities accumulate, strengthen and interact, causing multiple forms of discrimination that lead to differences in the exercise of rights.

- Short-, medium- and long-term social protection measures to deal with the effects of the pandemic must consider the well-being of the entire population, especially that of groups that experience multiple forms of exclusion and that suffer most acutely from the impacts of the crisis (see table 3). Therefore, social protection and well-being must be seen from a perspective of universalism that is sensitive to differences, i.e. taking into account the needs of specific groups and the lacks and discrimination they face.

Table 3 | Populations most affected by the socioeconomic impacts of COVID-19

\begin{tabular}{ll}
\hline Population & Area affected by the pandemic \\
\hline Women & Physical and mental health \\
Low- and lower-middle income strata & Nutrition \\
Informal workers & Education \\
Female paid domestic workers & Labour income \\
Children and adolescents & Child labour \\
Young people & Access to basic services (water, sanitation, electricity, \\
Older persons & gas, digital technologies) \\
Rural population & Unpaid care work \\
Indigenous peoples & Intrafamily violence \\
Afrodescendants & \\
Persons with disabilities & \\
Migrants & \\
Homeless persons & \\
\hline
\end{tabular}

Source: Economic Commission for Latin America and the Caribbean (ECLAC).

- The most affected groups account for a large percentage of the population of the countries in the region. For example, in the case of Brazil, estimates made by the Brazilian senate's Independent Fiscal Institution (IFI) and based on data up to 1 May 2020 indicate that half the population (111 million people) could require economic assistance to deal with the effects of the pandemic, which would cost more than US\$37 billion. This would mean more than doubling the scope of current measures, which provide for some 50 million people at a cost of some US\$ 17 billion (Folha de S. Paulo, 2020).

- While the crisis affects the entire workforce, the situation of informal workers of both sexes, and especially that of women and young people, indigenous people, people of African descent and migrants, results from the confluence of the axes of inequality and constitutes a hard core of vulnerability. The vast majority of these workers do not have sufficient savings to face the crisis in a scenario where, in addition, remittances may also suffer a sharp contraction.

- Physical distancing measures prevent informal workers from pursuing their activities and generating income to keep themselves out of poverty. Most have little or no access to social security, and thus limited ability to benefit from unemployment insurance or access to health care. Only eight Latin American and three Caribbean countries have unemployment insurance.

- The increase in informal work in the face of rising unemployment will make it difficult for informal workers and their families to obtain income to maintain a decent standard of living. This situation will also put pressure on the financial sustainability of social protection systems through the reduction of direct contributions and possible reductions in coverage. 
- Women are in a particularly vulnerable situation. As they are more precariously employed and account for a larger percentage of informal workers $(54.3 \%$ in 2016 , compared with $52.3 \%$ of men (ILO, 2018)), they are more exposed to the risk of unemployment. Female paid domestic workers (11.4\% of employed women), many of whom are migrants, indigenous or of African descent, are in a particularly complex situation. Few have access to social security, and they have less protection in scenarios of sustained unemployment. Since they cannot work remotely, adjustments to the budgets of employing families increase the uncertainty of their pay, especially if —as is often the case - they have no formal contract.

- In a context of confinement, school closures and the need for care should one or more family members become infected, the burden of unpaid domestic work assumed by women, adolescent girls and girls, and cases of violence against them, increase significantly.

- Children and adolescents have been affected by the closure of schools. As of 27 April 2020, 35 countries in the region had suspended classes at all levels of education, affecting more than 115 million students from preschool to tertiary level (UNESCO, 2020). Although 21 of these countries have established forms of continuity through distance-learning, this may widen learning gaps between students in public and private schools to the detriment of those in the lowest-income households, who have limited or no access to communication devices or the Internet and live in overcrowded conditions, with adults who have lower levels of education. Should the suspension of classes become prolonged, the risk of dropping out of school will increase, particularly in households whose income has fallen sharply. This would also increase the risk to children's and adolescents' mental health owing to confinement and family stress.

- The healthy development of children and adolescents is at risk. If school feeding programmes are not maintained, the nutrition and diet of the student population in the most vulnerable sectors will deteriorate. Increased child undernutrition and malnutrition owing to overweight are critical risks that must be prevented.

- Children from the poorest families are likely to be forced into the labour market, which would increase child labour rates (already $7.3 \%$ of children aged $5-17$, some 10.5 million children (ILO, 2018)). The possible increase in the burden of unpaid domestic and care work must also be considered in the case of girls and adolescent girls.

- In a situation of rising unemployment and restricted household budgets, young people will face a more adverse scenario with respect to their opportunities for educational continuity and entry into the labour market, which will affect their social and labour inclusion trajectories, especially among those belonging to low-income strata. This is particularly serious in countries where the youth unemployment rate is structurally much higher than the average for the economy.

- People over $\mathbf{6 0}$ years of age, or about 13\% of the region's population (85 million people), face higher mortality in the pandemic. Therefore, they require greater specialized and critical health care. The isolation in which many of them live also limits their ability to respond to the disease, creates risks to their food security and can affect their mental health.

- The crisis may deepen the inequalities and social and labour exclusion suffered by indigenous and Afrodescendent peoples, who account for a large percentage of unskilled self-employed workers and earn lower wages than men who are neither indigenous nor Afrodescendent, and the situation is particularly serious for women. Indigenous women's hourly labour income is less than one third of that of non-indigenous, non-Afrodescendent men with the same level of education. Structural discrimination and racism also hinder effective access to health services for indigenous people and people of African descent.

- Inequalities in access to water, sanitation, health systems and housing (and the consequent overcrowding), as well as inequality in health conditions, can translate into higher rates of infection and mortality from COVID-19 among rural populations, marginal urban populations, indigenous peoples and people of African descent. For example, as of 9 April 2020, Afrodescendants accounted for $45.2 \%$ of deaths from COVID-19 in Brazil, despite representing only $37.4 \%$ of hospitalizations (Ministry of Health of Brazil, 2020). 
- Confinement measures can expand the barriers faced by persons with disabilities in accessing the education system and decent work with sufficient income and social protection. This is especially serious for those whose economic situation precludes having the devices on which to continue educational or work activities from home.

- Migrants are affected by the closure of borders, the difficulties of movement and the increase in unemployment. Their access to health systems and social protection is inadequate because of the scarce resources available for migrants, and because of their fear of being identified when these resources are available. These problems are exacerbated in the case of migrant children - whether or not they are accompanied - who are internally displaced, and in light of the possible increase in xenophobia and discrimination and racism against migrants (UNICEF, 2020).

- Homeless people are overexposed to the risk of contracting COVID-19 because of their lack of housing, food and access to health. This is also the case for persons deprived of their freedom, owing to the high risk of infection resulting from their confinement.

\section{Emergency measures and strengthening of existing} social protection measures

- The first case of COVID-19 in Latin America and the Caribbean was recorded in Brazil on 26 February 2020. On 13 March, governments across the region began to announce social protection measures in response to the sudden drop in workers' and household incomes, particularly among the most vulnerable populations (see table 4).

Table 4 | Latin America and the Caribbean: social protection measures in response to COVID-19

\begin{tabular}{|c|c|c|c|c|}
\hline Cash transfers ${ }^{a}$ & In-kind transfers & $\begin{array}{l}\text { Provision of basic } \\
\text { services }\end{array}$ & $\begin{array}{l}\text { Social protection } \\
\text { for formal workers }\end{array}$ & $\begin{array}{l}\text { Other direct support } \\
\text { to individuals } \\
\text { or families }\end{array}$ \\
\hline $\begin{array}{l}\text { - New cash transfer } \\
\text { programmes } \\
\text { - Expansion } \\
\text { of existing } \\
\text { programmes (early } \\
\text { disbursement, } \\
\text { increased amounts, } \\
\text { wider coverage) }\end{array}$ & $\begin{array}{l}\text { - Food } \\
\text { - Medicines } \\
\text { - Masks } \\
\text { - Cleaning products }\end{array}$ & $\begin{array}{l}\text { Suspension or } \\
\text { waiver of bill } \\
\text { payment for: } \\
\text { - Water } \\
\text { - Electricity } \\
\text { - Gas } \\
\text { - Communications } \\
\text { (telephone, } \\
\text { Internet, TV) }\end{array}$ & $\begin{array}{l}\text { - Reduced exposure } \\
\text { to COVID-19 } \\
\text { (teleworking) } \\
\text { - Income and } \\
\text { employment } \\
\text { protection } \\
\text { (unemployment } \\
\text { insurance, sick } \\
\text { leave, bans on } \\
\text { dismissal) }\end{array}$ & $\begin{array}{l}\text { - Tax relief } \\
\text { - Loan and } \\
\text { mortgage payment } \\
\text { accommodations } \\
\text { - Price control }\end{array}$ \\
\hline
\end{tabular}

Source: Economic Commission for Latin America and the Caribbean (ECLAC)

a Transfers for persons and households in situations of poverty and vulnerability, including informal workers.

\section{Social protection for populations living in poverty and vulnerability}

- The pandemic has made it more difficult for people —especially the poorest and most vulnerableto meet their basic needs. It is therefore necessary to guarantee income, food security and basic services for a large group of people who have been rendered extremely vulnerable and who were not necessarily included in existing social programmes before the pandemic.

- There is a crucial need for comprehensive and up-to-date social records to identify the target population for this support. To prevent the spread of the virus, social programmes should seek to deter crowding of people upon collection of payments and food. In this regard, electronic payment systems are very important.

- Territorial targeting is an effective tool for the rapid delivery of State benefits and entitlements to relevant populations.

- Between 13 March and 24 April 2020, 29 countries in the region adopted 126 social protection measures to help households facing the greatest poverty, vulnerability and insecurity to weather the pandemic. In the second half of March, the number of countries and measures increased almost every day (see figure 3 and annex table A1). 
Figure 3 | Latin America and the Caribbean (29 countries): social protection measures for the population living in poverty and vulnerability announced in response to the COVID-19 pandemic, 13 March-24 April 2020

(Number of measures)

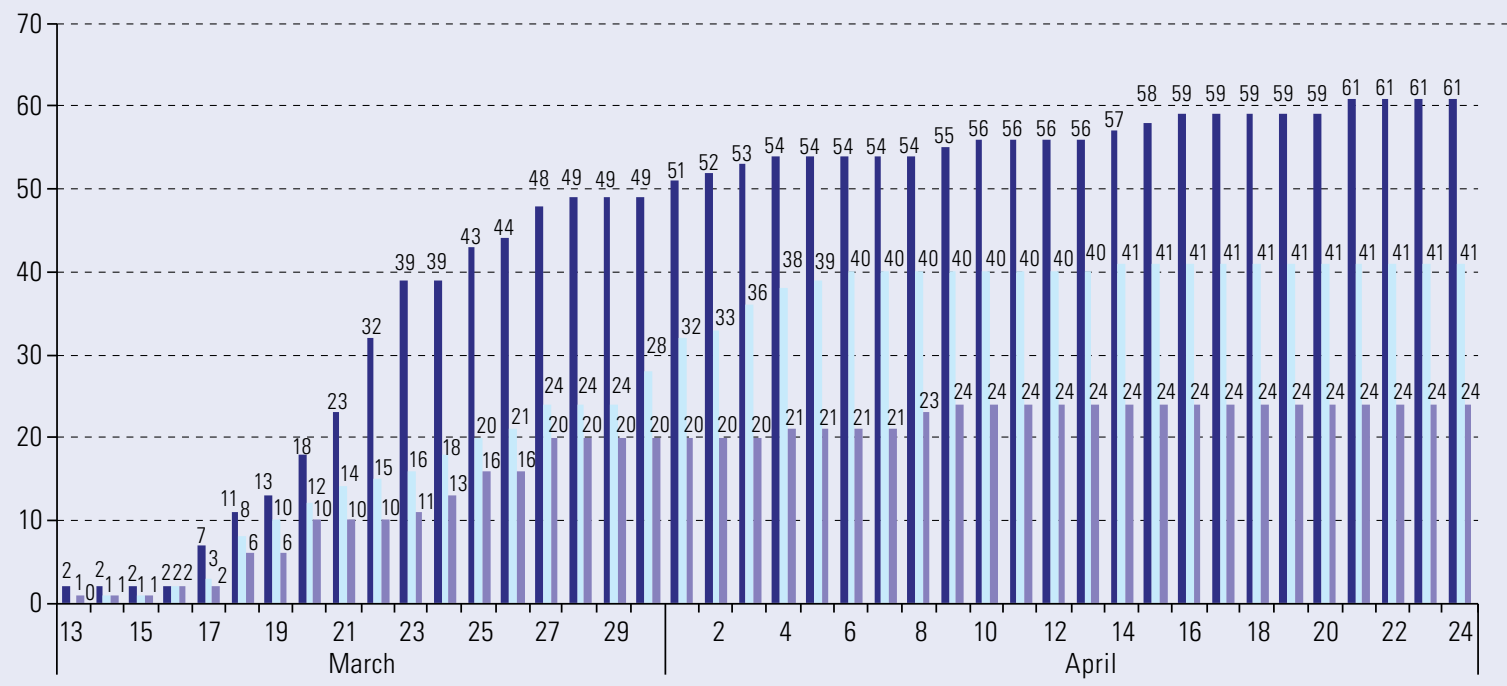

Cash transfers Provision of food and medicines

Basic services

Source: Economic Commission for Latin America and the Caribbean (ECLAC).

a Antigua and Barbuda, Argentina, Bahamas, Barbados, Belize, Bolivarian Republic of Venezuela, Brazil, Chile, Colombia, Costa Rica, Cuba, Dominican Republic, Ecuador, El Salvador, Grenada, Guatemala, Guyana, Haiti, Honduras, Jamaica, Mexico, Panama, Paraguay, Peru, Plurinational State of Bolivia, Saint Lucia, Saint Vincent and the Grenadines, Trinidad and Tobago, and Uruguay.

- The main measures implemented are the provision of food -a key support pillar for the populations of Guatemala and Honduras - and the establishment of new cash transfers, which accounted for $33 \%$ and $27 \%$ of the measures adopted, respectively. The next most common measures are the suspension of payments for basic services such as water, electricity, telephone and Internet (19\%) and increases in the amounts allocated under existing cash transfers (13\%). Early disbursement of existing cash transfer programmes accounts for $5 \%$ of measures adopted, while the expansion of population coverage of existing cash transfers represents $4 \%$ (see figure 4 ).

Figure 4 | Latin America and the Caribbean (29 countries):a social protection measures for the population living in poverty and vulnerability announced in response to the COVID-19 pandemic, by type of measure, at 24 April 2020 (Number of measures and percentage distribution)

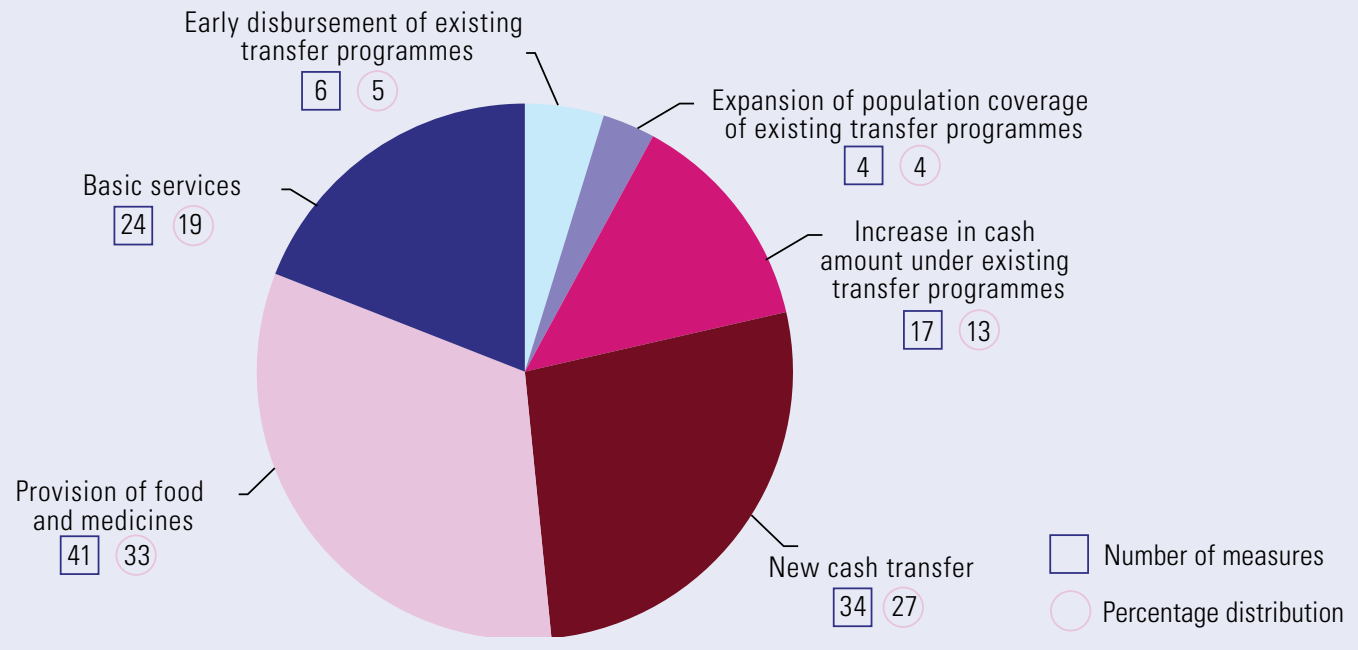

Source: Economic Commission for Latin America and the Caribbean (ECLAC).

a Antigua and Barbuda, Argentina, Bahamas, Barbados, Belize, Bolivarian Republic of Venezuela, Brazil, Chile, Colombia, Costa Rica, Cuba, Dominican Republic, Ecuador, El Salvador, Grenada, Guatemala, Guyana, Haiti, Honduras, Jamaica, Mexico, Panama, Paraguay, Peru, Plurinational State of Bolivia, Saint Lucia, Saint Vincent and the Grenadines, Trinidad and Tobago, and Uruguay. 
- The conditionalities have been lifted for a number of existing cash transfer programmes because families have been unable, for example, to send their children to school.

- Four modalities of cash transfers, which are not mutually exclusive, have been announced to tackle the effects of the COVID-19 pandemic on poor and vulnerable households:

(i) New cash transfers. This is the most widespread modality in the region (23 countries). For example, the Plurinational State of Bolivia announced the creation of the Family Grant (Bono Familia), under which a one-time payment of 500 bolivianos (US\$ 70) is provided to low-income families with children in primary school who are unable to receive school breakfasts during the quarantine. Argentina implemented the Emergency Family Income (Ingreso Familiar de Emergencia), a transfer of 10,000 Argentine pesos (about US\$154) to 3.6 million households for one month initially, set to be extended for a further month. Brazil adopted an emergency grant for independent or informal workers with a monthly per capita income of less than half the minimum wage and a household income of less than three times the minimum wage. The grant amounts to 600 reais per person per month (US\$ 117), with a maximum of 1,200 reais per family, for three months; femaleheaded single-parent households will receive 1,200 reais. At the subnational level, Mexico City established a new transfer for an initial period of 45 days.

(ii) Increases in the amount allocated under existing cash transfers. This measure has been adopted by 11 countries. Argentina has increased the amounts disbursed to all recipients covered by programmes such as the Universal Child Allowance and the Pregnancy Social Protection Allowance, as well as non-contributory pensions. The supplementary allowances range between US\$ 44 and US\$150, with the highest amount going to disability pensions. Colombia announced an additional transfer for persons covered by the Youth in Action, Families in Action and Colombia Mayor programmes, and Paraguay announced an additional payment in April for recipients of the Tekoporã conditional transfer programme. Uruguay announced a one-time doubling of the amounts provided through the Uruguay Social Card and the Family Allowances-Equity Plan. Lastly, Mexico City increased the amount of the transfers under the Mi Beca para Empezar programme that covers all students enrolled in public elementary schools.

(iii) Early disbursement of existing cash transfers. As of 24 April 2020, Brazil, Colombia, Mexico and Paraguay had announced early payment of cash transfers primarily for older persons and persons with disabilities. Paraguay announced early disbursement of the Maintenance for Older Persons in Poverty, while Mexico advanced the payment of the equivalent of four months' pensions to 8 million older persons and 1 million persons with disabilities.

(iv) Expansion of population coverage for existing cash transfers. Four countries announced an increase in the number of recipients of existing programmes. Argentina planned to issue more than 1.5 million additional cards for transfers under the food card programme for the purchase of goods in the basic food basket. Brazil indicated that 1.2 million more people would be covered by the Bolsa Família programme. Mexico will extend the coverage of the Sembrando Vida programme to 200,000 farmers, and Trinidad and Tobago announced the expansion of its food card programme to cover previously excluded families with children eligible for school feeding and families whose members have been laid off or have seen their incomes reduced during the pandemic.

- As of 11 April, 14 countries had set up cash transfers to compensate for dwindling incomes of informal workers and other vulnerable workers such as the self-employed. This is an innovative social protection mechanism in the region. Transfers consist of one-time or periodic payments (for a maximum of three months) and the amount transferred to each person or household varies considerably (see figure 5). In Costa Rica, for example, the Bono Proteger is an individual monthly transfer of 125,000 colones (US\$220) for three months to informal workers and independent workers, as well as to persons who have been made redundant, have had their employment contract suspended or their working hours cut by more than $50 \%$. Individuals whose working hours have been reduced by $50 \%$ or less will receive 62,500 colones per month (US\$110). 
Figure 5 | Latin America and the Caribbean (13 countries): amount of cash transfers for informal workers, by recipient (person or family) and duration, at 11 April 2020a

(Dollars)

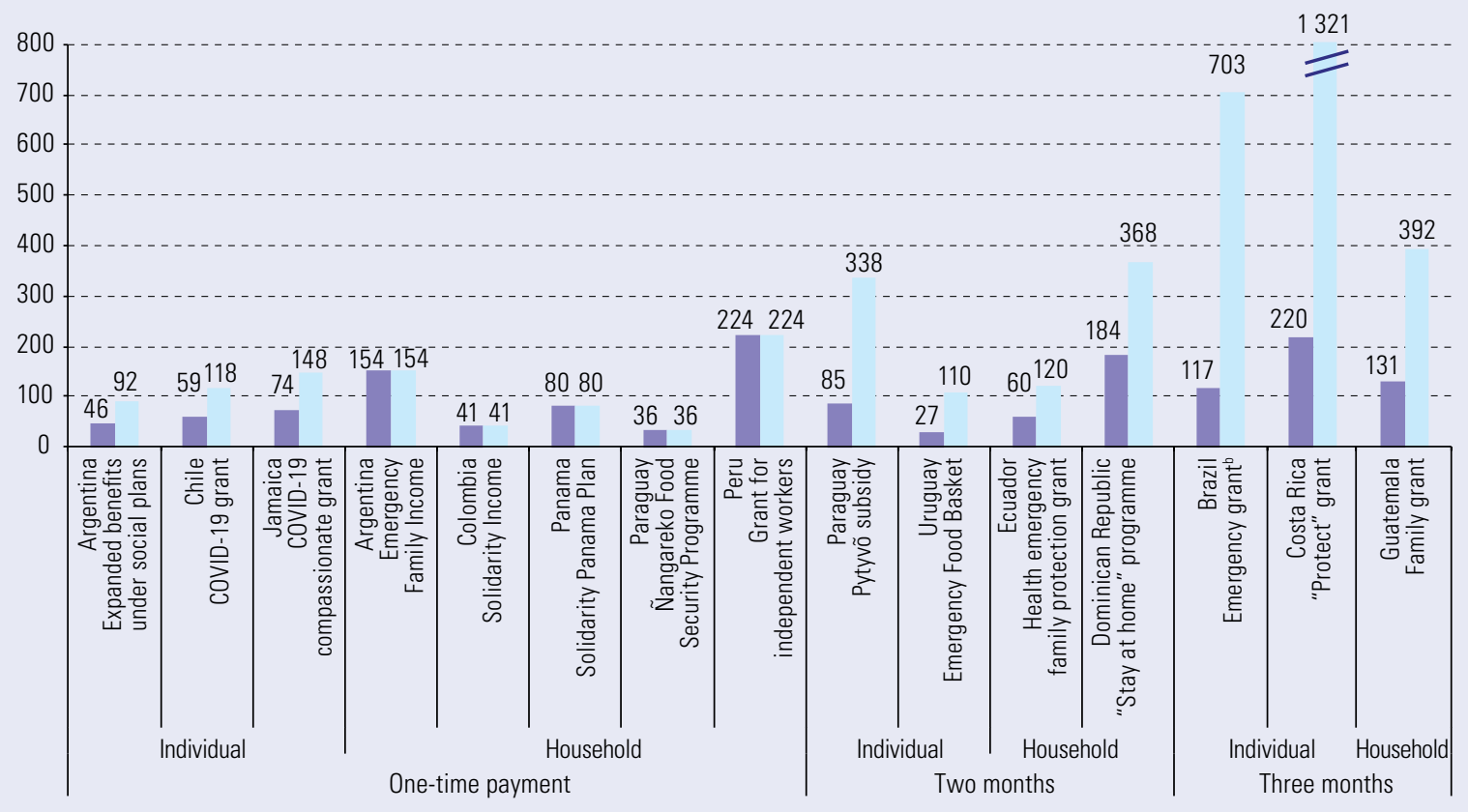

Monthly amount per recipient

Monthly total per household

Source: Economic Commission for Latin America and the Caribbean (ECLAC).

a For measures where the recipient is the individual (or the "family dependant", i.e. a dependent person such as a child or an adolescent), the total amount per family is calculated assuming that two amounts are received. The Bolivarian Republic of Venezuela has created a Discipline and Solidarity Grant for workers in the informal economy; however, no information is available on the amount of the transfer.

${ }^{b}$ Also includes persons with suspended contracts, reduced working hours or own-account workers whose income has been affected by COVID-19.

- ECLAC estimates that, as of 24 April 2020, the cash transfers implemented in 22 countries to support families in situations of poverty and vulnerability during the crisis covered approximately $\mathbf{9 0 . 5}$ million households (385.7 million people, or $58 \%$ of the population). Projected expenditure over three months will amount to some US\$ $\mathbf{3 6 . 8 3}$ billion, about $0.7 \%$ of GDP for 2020 . The countries with the most extensive household coverage in absolute terms are Brazil (38.2 million), Colombia (11.3 million), Argentina (8.4 million) and Peru (4.8 million). This figure is almost twice the annual cost of conditional cash transfers prior to the crisis, which was about $0.35 \%$ of GDP.

- Food provision is a measure that has been adopted by 24 countries to date, either through direct delivery to households, or through schools or community kitchens. In many countries, food has been supplied through existing school feeding programmes, which have been maintained despite school closures and adapted to distribution schedules and increased rations to avoid large gatherings.

- Costa Rica is one of the countries providing food supplies: the Alimentos en Casa initiative offers delivery of food and medicine to households with children and pregnant and breastfeeding mothers. In the Dominican Republic, food baskets and prevention kits for vulnerable families are delivered to schools, through the social assistance plan of the Office of the President (PASP), State-run soup kitchens (CEED), the National Institute for Comprehensive Early Childhood Care (INAIPI) and childcare facilities. The Bolivarian Republic of Venezuela provides food baskets to students enrolled in official educational establishments and to the most vulnerable families. Uruguay is also providing an emergency food basket to informal workers who are not receiving other State entitlements.

- Measures to guarantee and facilitate the supply of basic services to the most vulnerable households during social distancing have been adopted in 17 countries. For example, Guatemala, Honduras and Panama announced measures to ensure electrical power supply for households through the reconnection of services, subsidies and payment facilities. Argentina, Chile, Ecuador and El Salvador, among others, have taken measures to prevent the disconnection of all basic household services, including water, telephone and Internet, on the grounds of non-payment. 
- Some of these measures have been implemented in collaboration with the private sector and civil society. In Colombia, a virtual solidarity contribution network was set up to purchase basic products and foodstuffs for vulnerable populations unable to access the social security benefits currently available. In Ecuador, a new platform was launched to purchase food baskets to be distributed to vulnerable families across the country by the Armed Forces. In the Cayman Islands, the Department of Education Services has partnered with a non-governmental organization to distribute supermarket food vouchers.

\section{Social protection for formal workers}

- Most countries have halted non-essential services in order to maintain social distancing. Although formal workers in essential sectors still receive an income, many formal workers have ceased to be paid or are paid only part of their salary. Employees and owners of micro, small and medium-sized enterprises are among those in this situation.

- Some countries have adopted economic support measures for health workers, who are at great risk of infection. For example, Argentina introduced an exceptional bonus for health personnel of 5,000 Argentine pesos (US\$ 76) per month for four months (April to July).

- Two types of social protection measures for formal workers have been adopted. The first aims to reduce workers' exposure to the virus and ensure business continuity, the second is intended to protect income and employment (see figure 6). There are also indirect measures to protect formal employment which are not analysed in this report, including support for enterprises in the form of rescheduled debt and tax payments or special loans, for example.

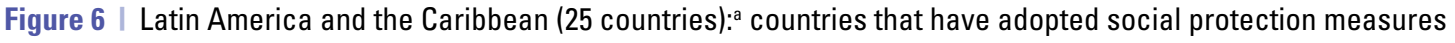
for formal workers, as of 11 April 2020

(Number of countries)

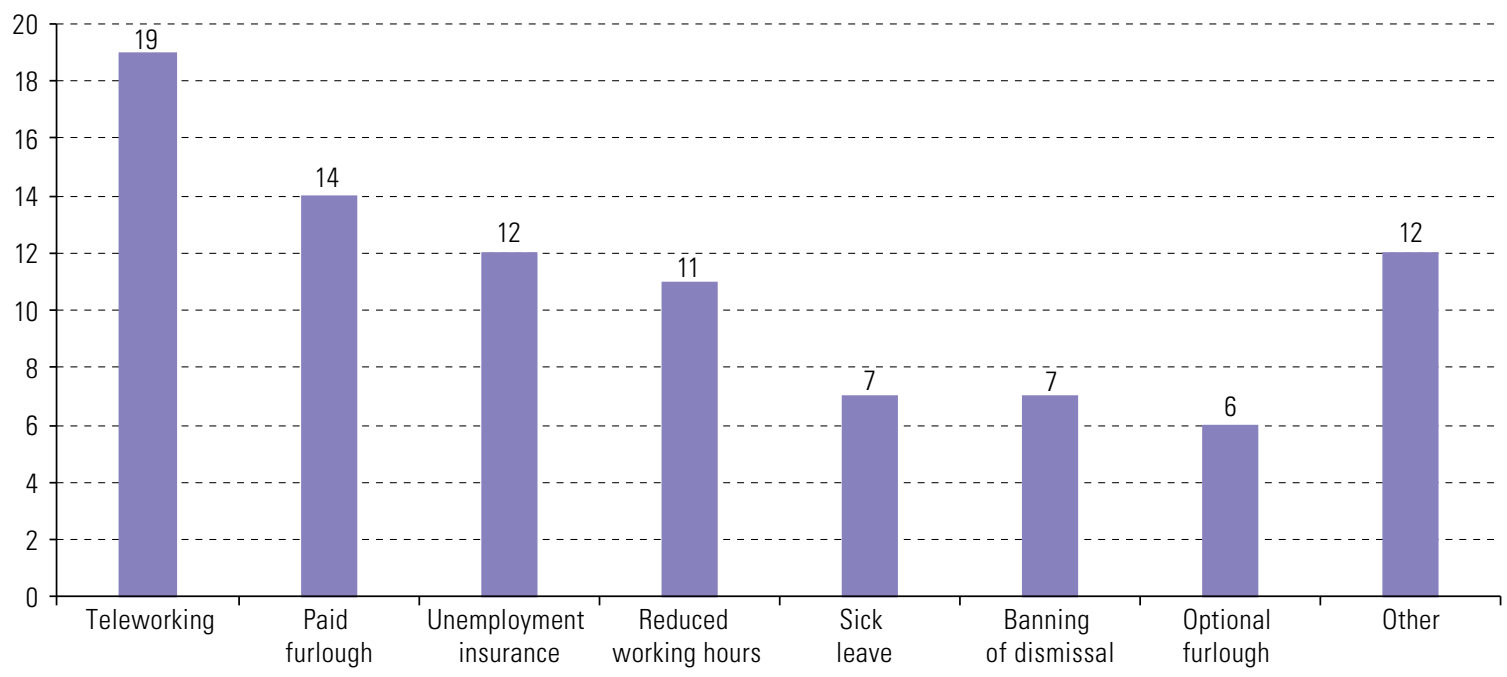

Source: Economic Commission for Latin America and the Caribbean (ECLAC).

a Argentina, Bahamas, Barbados, Belize, Bolivarian Republic of Venezuela, Brazil, Chile, Colombia, Costa Rica, Cuba, Dominican Republic, Ecuador, El Salvador, Grenada, Guatemala, Guyana, Haiti, Jamaica, Mexico, Panama, Paraguay, Peru, Plurinational State of Bolivia, Trinidad and Tobago, and Uruguay.

- Teleworking is being used as a means of physical distancing in the public and private sectors. In Chile, public servants in at-risk population groups are allowed to work from home. In Argentina, as part of mandatory social isolation measures to prevent contagion, teleworking has been adopted for all public and private sector workers who can work from home. Other measures aim to ensure health and safety in the workplace by requiring employees to wear masks or maintain physical distance.

- In 11 countries, shorter working hours have been adopted to help to minimize workplace exposure and protect jobs in the companies concerned. Examples include limited opening hours for non-essential businesses in Jamaica, limited banking hours in Guyana or reduced working hours in the public sector in Paraguay. Costa Rica adopted legislation authorizing the temporary reduction of working hours, which will serve to protect workers' jobs following the declaration of a national emergency. 
- A wide range of policies have been introduced to protect the incomes of formal workers, including guaranteed payment of wages during absence from work, paid sick leave, activation of unemployment insurance measures, banning of dismissal and optional leaves of absence.

- The payment of wages during absence from work is a measure aimed particularly at workers who are most vulnerable to the pandemic, such as older persons, persons with pre-existing health conditions and pregnant women. In some cases, this is also applied to formal workers who are unable to report to work because of the health emergency. In Mexico, full payment of wages has been maintained for all workers in non-essential activities. In the Dominican Republic, companies will pay a week's salary to private sector workers who are not yet entitled to vacation. In Peru, in cases where the type of work cannot be performed remotely, companies must guarantee payment of employees' wages during their absence. Trinidad and Tobago has granted free paid days to workers with children.

- Unemployment insurance and sick leave have also been used to guarantee an income for formal workers who are out of work. In Argentina, for example, legally registered wage workers who are dismissed without good cause will receive a monthly payment, family allowances and medical coverage through unemployment insurance. The duration of coverage will vary based on the number of years of effective service and contribution to the social security system (Fondo Nacional de Empleo). In other cases, a fund has been set up to provide sectoral unemployment insurance for workers in the most severely affected economic sectors, such as the tourism sector in the Caribbean countries. Brazil approved the payment of 15 days of sick leave for persons infected with the virus.

- Various measures banning dismissal have also been implemented to protect employment and labour income. These measures vary considerably and take into account declarations of states of emergency and health-related restrictions that prevent access to the workplace and generally prohibit the use of COVID-19 as a cause for dismissal, or impose a moratorium on dismissals. In Argentina, for example, the national government prohibited unfair dismissals or dismissal on the grounds of lack or reduction of work or force majeure for a 60-day period. El Salvador has banned the dismissal of any workers who have been quarantined.

- In many cases, optional furlough has been used in connection with advance vacation, as in Brazil and Paraguay, and job-sharing or compensatory time off. In the latter case, compensatory time off is based on a "time bank" that allows employees to accumulate working hours or to owe them to their employer. Such agreements must be formally negotiated on an individual or collective basis between workers and the employer.

- Some other measures include payroll subsidies for companies and economic sectors in vulnerable situations and loans to help companies retain their workers. In Argentina, the Production Recovery Programme (REPRO) pays a fixed monthly sum equivalent to the minimum wage for up to 12 months with a view to supplementing the labour income of workers in companies whose sales revenues have dropped because of the emergency. Peru passed an emergency decree granting all employers a subsidy not exceeding $35 \%$ of the gross monthly salaries of workers earning up to 1,500 soles (US\$ 436). In Chile, workers earning the minimum wage (301,000 Chilean pesos) in February 2020 will receive an additional 59,200 pesos (US\$ 70); the allowance is applied on a sliding scale for wages up to 384,363 pesos. This guaranteed minimum income, which was already in place before the health emergency as part of the response to the recent social unrest, is expected to cover 670,000 workers.

- In the area of pensions, four types of measures have been implemented: (i) payment of exceptional bonuses to retirees who receive the lowest pensions in the pension system, sometimes supplemented with smaller amounts for those with higher pensions (in Argentina, for example, an exceptional bonus of 3,000 Argentine pesos (US\$ 45) is paid to recipients of very low pensions); (ii) advance pension payments for a certain number of months, as in the Bahamas, Belize and Brazil; (iii) withdrawal of funds from individual capitalization accounts by independent workers (in Peru, independent workers who have not contributed to their pension fund in the last 12 months may withdraw funds from their account for up to 2,000 soles, or US\$ 590); and (iv) suspension of employers' contributions (in Argentina, for example, businesses in financial difficulty may postpone or reduce up to $95 \%$ of employer contributions). In addition, the effects on pension systems overall must be considered (see box 1). 


\section{Box 1 | Effects of the crisis on pension systems}

Pension systems will be affected by the pandemic. Pension system affiliation and contributions will shrink, especially in the countries most exposed to increased unemployment and informality. This will have an impact on the income from contributions and on the density of contributions at retirement, and could ultimately reduce payouts and deepen current gender inequalities.

Pay-as-you-go systems with reserves based on the collective partial capitalization model will likely face financial effects linked to the decline in income from contributions and in the profitability of reserve funds.

Systems whose main component is individual capitalization or that include a complementary component in parallel or mixed models will see a sharp reduction in cumulative funds and in pension amounts for those about to retire. This situation may particularly affect Chile, the Dominican Republic, El Salvador, Mexico and the Plurinational State of Bolivia, which have an individual capitalization model (substitutive model), and also Colombia, Costa Rica, Panama, Peru and Uruguay, which have parallel or mixed systems.

In individual capitalization systems, gross returns at retirement may be affected by nominal losses and changes in the value of the funds. While the effects must be analysed over the long term and the existence of multifunds can mitigate this problem, this does not completely eliminate the risk, which is greater for those who are about to retire or are forced to retire for health or disability reasons.

It is important to safeguard the financial sustainability of pension systems and especially the right of individuals to access adequate benefits upon retirement. After the emergency, the discussion already under way on pension system reforms in several countries of the region will be pursued further, considering that reforms targeting only individual saving capacity do not address social protection demands or the importance of progress in solidarity mechanisms.

Source: Economic Commission for Latin America and the Caribbean (ECLAC).

\section{Other direct support to individuals and families}

- Countries have adopted other measures that mitigate and reduce spending by individuals and families. As of 24 April 2020, 22 countries have announced 45 additional measures, of which $60 \%$ are credit and mortgage payment facilities, $22 \%$ are tax relief and $18 \%$ are price controls (see figure 7).

Figure 7 | Latin America and the Caribbean (22 countries):a other measures of direct support to individuals and families announced to tackle the effects of the COVID-19 pandemic, by type of measure, as of 24 April 2020

(Number of measures and percentage distribution)

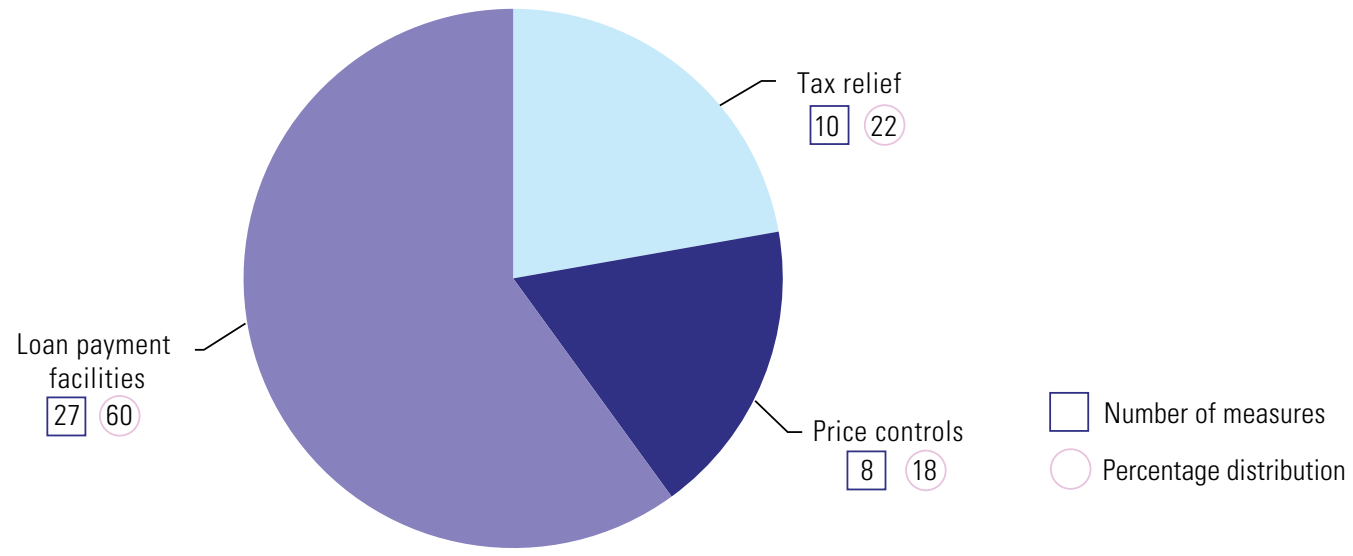

Source: Economic Commission for Latin America and the Caribbean (ECLAC).

a Argentina, Barbados, Bolivarian Republic of Venezuela, Chile, Colombia, Costa Rica, Cuba, Dominica, Dominican Republic, Ecuador, El Salvador, Grenada, Guatemala, Guyana, Honduras, Jamaica, Mexico, Panama, Paraguay, Plurinational State of Bolivia, Trinidad and Tobago, and Uruguay. 
- To date, 20 countries have offered credit payment facilities to households, including deferred payment of instalments, loan rescheduling and refinancing, exemption from payment or suspension of interest on arrears and penalties for the duration of the emergency. In three countries, it was the banking sector that announced the measures, while in the others they were public initiatives imposed on private banks or the result of agreements between governments and banks.

- Seven countries have granted tax relief to the worst affected families, consisting mainly of exemption from tax fines, suspension of collection measures and evictions for non-payment, and facilities for payment of taxes in the months following the end of the quarantine period. In addition, six countries have capped the prices of specific food items and medicines, so that price increases do not further affect the poorest families and to ensure adequate supplies.

\section{A basic income to meet needs and support consumption}

- To address the socioeconomic impact of the crisis, ECLAC proposes that governments guarantee temporary cash transfers to meet basic needs and support household consumption, which will be crucial to achieving a sound, relatively rapid recovery.

- From a long-term perspective, ECLAC reiterates that these transfers need to be ongoing, should reach beyond those living in poverty and cover broad strata of the population that are highly vulnerable to falling into poverty, such as the low-income non-poor and the lower-middle income strata. This would make it possible to move towards a universal basic income that could be implemented gradually over a period suited to each country's situation (see box 2). This consideration is important, because overcoming the pandemic will take time and societies will have to live with the coronavirus, which will hamper economic and production recoveries.

Box 2 | A proposal for a universal basic income in Mexico

As a result of the health crisis, there has been growing discussion of a universal citizen's income. To implement such a measure, an amount must be determined per person that is consistent with the objective of eradicating poverty and improving income distribution.

In Mexico, two options have been considered: to provide a universal minimum wage or an amount equivalent to the urban welfare line or urban minimum welfare line, as estimated by the National Council for the Evaluation of Social Development Policy (CONEVAL). Providing a minimum welfare line equivalent to the cost of the food basket for urban areas (around US\$ 73 per month in March 2020) would take an outlay equivalent to 10.3\% of estimated GDP for 2020. A programme closer to the objectives of a universal basic income, providing a minimum wage (around US\$ 167 per month) or an amount equivalent to the food and non-food basket (around US\$ 144 per month) would raise the outlay to $23.5 \%$ and $20.2 \%$ of GDP, respectively. In view of these amounts, implementation of a universal citizen's income would need to be a gradual long-term process.

Source: Economic Commission for Latin America and the Caribbean (ECLAC).

- In the context of the COVID crisis, alternatives must be considered that have limited scope or duration, but which set the course for the actions that must be implemented once the pandemic is over.

n To estimate the cost of these cash transfers in the short run, it is considered that their minimum duration should be three months, although six months or a year would provide better protection to the population. The transfers would be per person and for an equivalent of one extreme poverty line (EPL), representing the per capita cost of acquiring a basic food basket, or one poverty line (PL), which allows other basic needs to be covered. The estimate does not take into account the costs of managing the transfers which, according to the International Labour Organization (ILO), would be in the region of $5 \%$ of the amount of the transfers (Durán-Valverde and others, 2019). 
- In terms of the target population, the cost of transfers has been calculated for five groups: (i) everyone (universal); (ii) all persons living in poverty; (iii) all informal workers aged 18-64 years; (iv) all children and adolescents aged 0-17 years; and (v) all persons aged over 65 . The different configurations of target population, transfer amounts and duration should take into account the reality of each country.

- The (weighted) average cost of cash transfers for the countries of the region ranges from a minimum of $\mathbf{0 . 2} \%$ of GDP for a transfer equivalent to one extreme poverty line (US\$ 67 in 2010 dollars) for three months for all those over age 65 to a maximum of $\mathbf{9 . 8 \%}$ of GDP for a transfer equivalent to one poverty line (US\$ 143) for six months for everyone (universal transfer) (see figure 8).

Figure 8 | Latin America (18 countries):a estimated cost of cash transfers equivalent to one poverty line and one extreme poverty line to address the impact of the COVID-19 pandemic, by target population, duration and total population coverage ${ }^{\text {bc }}$

(Percentages of GDP and of total population)

A. Poverty line

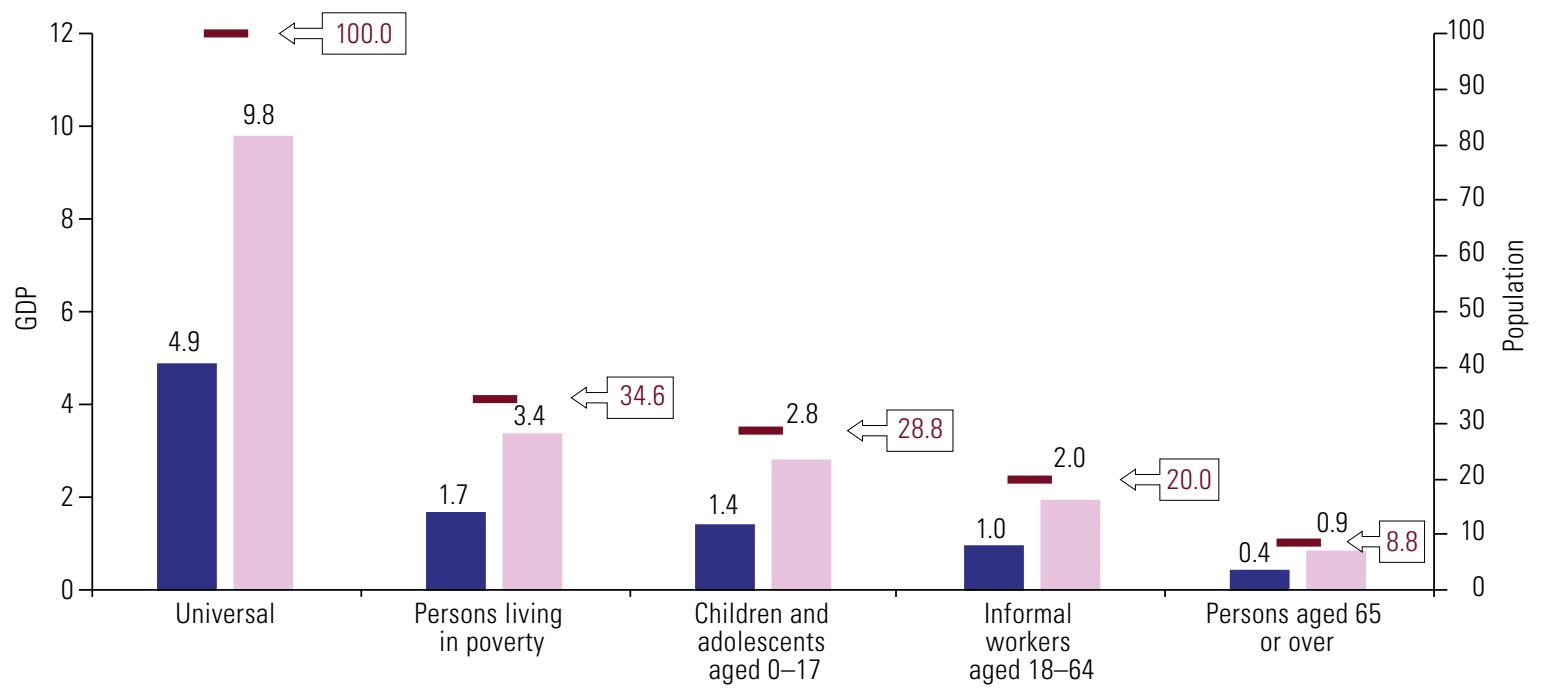

B. Extreme poverty line

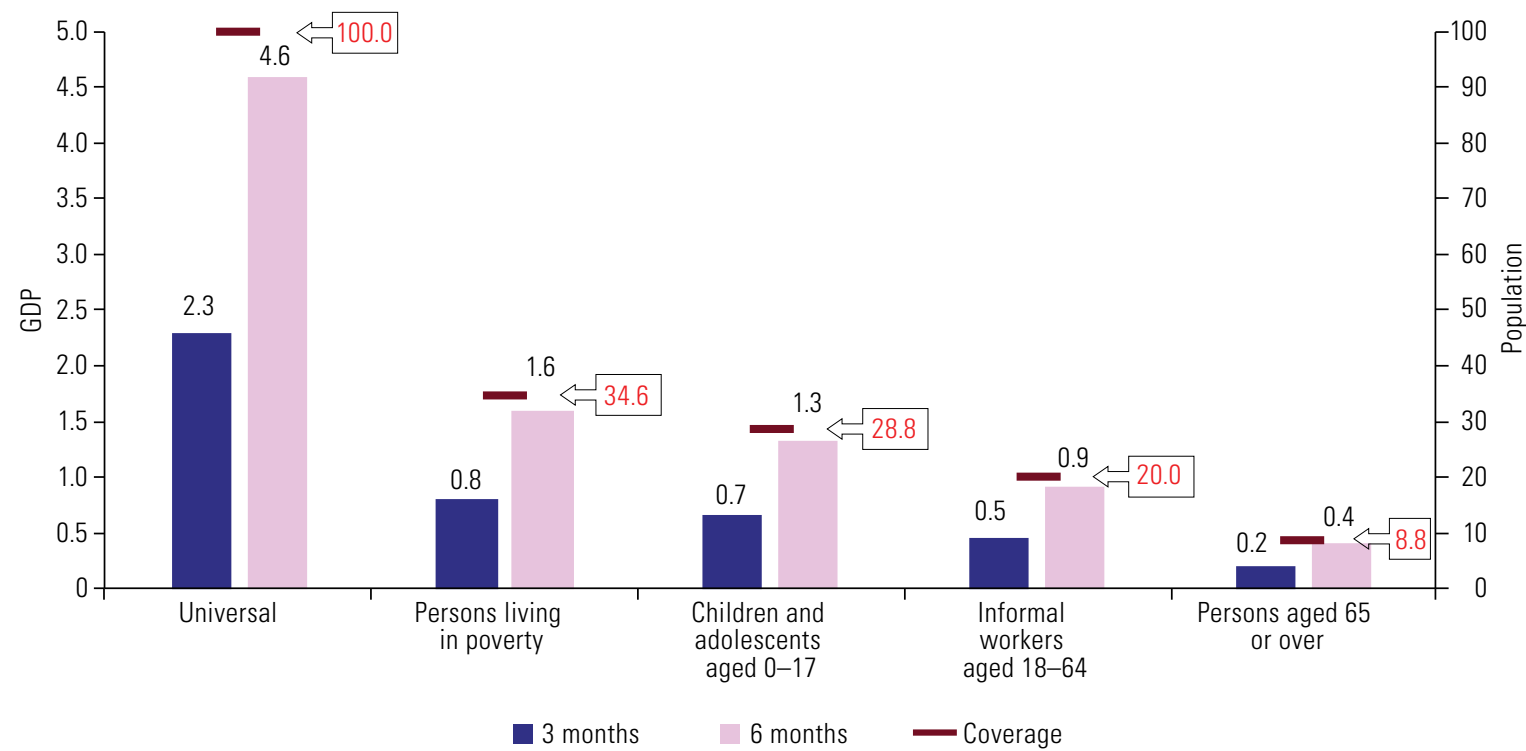

Source: Economic Commission for Latin America and the Caribbean (ECLAC).

a Argentina, Bolivarian Republic of Venezuela, Brazil, Chile, Colombia, Costa Rica, Dominican Republic, Ecuador, El Salvador, Guatemala, Honduras, Mexico, Nicaragua, Panama, Paraguay, Peru, Plurinational State of Bolivia and Uruguay.

b Estimate based on a 5.3\% drop in GDP in 2020 and considering a population living in poverty of 214.7 million in the same year. The administrative costs required to make the transfers have not been taken into account.

c The category "informal workers" comprises workers in low-productivity sectors, including: domestic service, unskilled own-account workers, unskilled workers in microenterprises and microentrepreneurs. 
- In addition to the question of financing, implementation of these transfers is subject to operational difficulties. From a health perspective, social distancing should be observed and transfers should be electronic. However, since a significant portion of the population does not use banking services, other solutions must be found, such as payments by mobile phone or distribution of cash, but avoiding mass gatherings. In addition, implementing transfers in the near term requires extensive up-to-date social records and consideration of the links with social protection systems and other existing mechanisms, such as unemployment insurance, pensions, family allowances and conditional transfers.

- By considering regional spending on non-contributory social protection programmes such as conditional transfer programmes and social pensions, it is possible to estimate the additional cost of implementing these transfers. The estimate is obtained by considering the total cost of spending on both programmes for universal transfers and for transfers to all persons living in poverty, spending on conditional transfer programmes for children and adolescents, and spending on social pensions for older persons. Since there were no specific transfers for informal workers before the current crisis, the costs of transfers for this population group are considered to be entirely additional.

- A transfer of an amount equivalent to one poverty line for six months would require additional expenditure of $\mathbf{2 . 8 \%}$ of GDP to cover all those who will be living in poverty in $\mathbf{2 0 2 0}$. Considering the $0.7 \%$ of regional GDP that the countries are spending to date on cash transfers and food supply in response to the emergency, the additional expenditure is $2.1 \%$ of GDP. In the other cases, the fiscal effort is $\mathbf{2 . 7 \%}$ of GDP for a transfer to all children and adolescents, $0.6 \%$ of GDP for those aged over 65 , and $9.2 \%$ of GDP for a transfer to all persons, i.e. a universal transfer (see figure 9).

- Given the limited fiscal space of the countries of the region, the most viable alternative in the current situation would be to transfer an amount equal to one poverty line for six months. This configuration should be adjusted or expanded according to each national situation.

Figure 9 | Latin America (18 countries):a estimated additional cost of cash transfers equivalent to one poverty line to address the impact of the COVID-19 pandemic, by target population and duration ${ }^{\mathrm{b}}$

(Percentages of GDP)

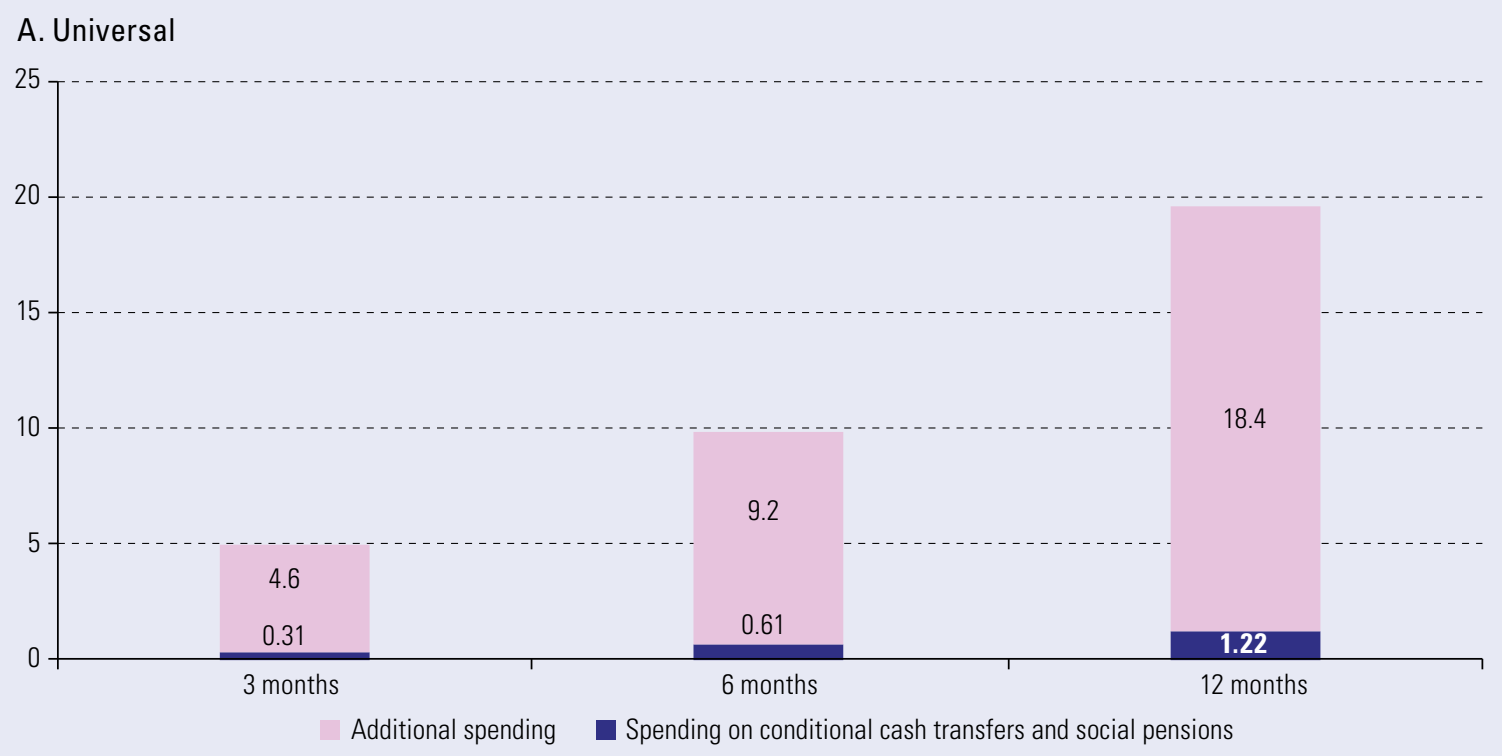


Figure 9 (concluded)

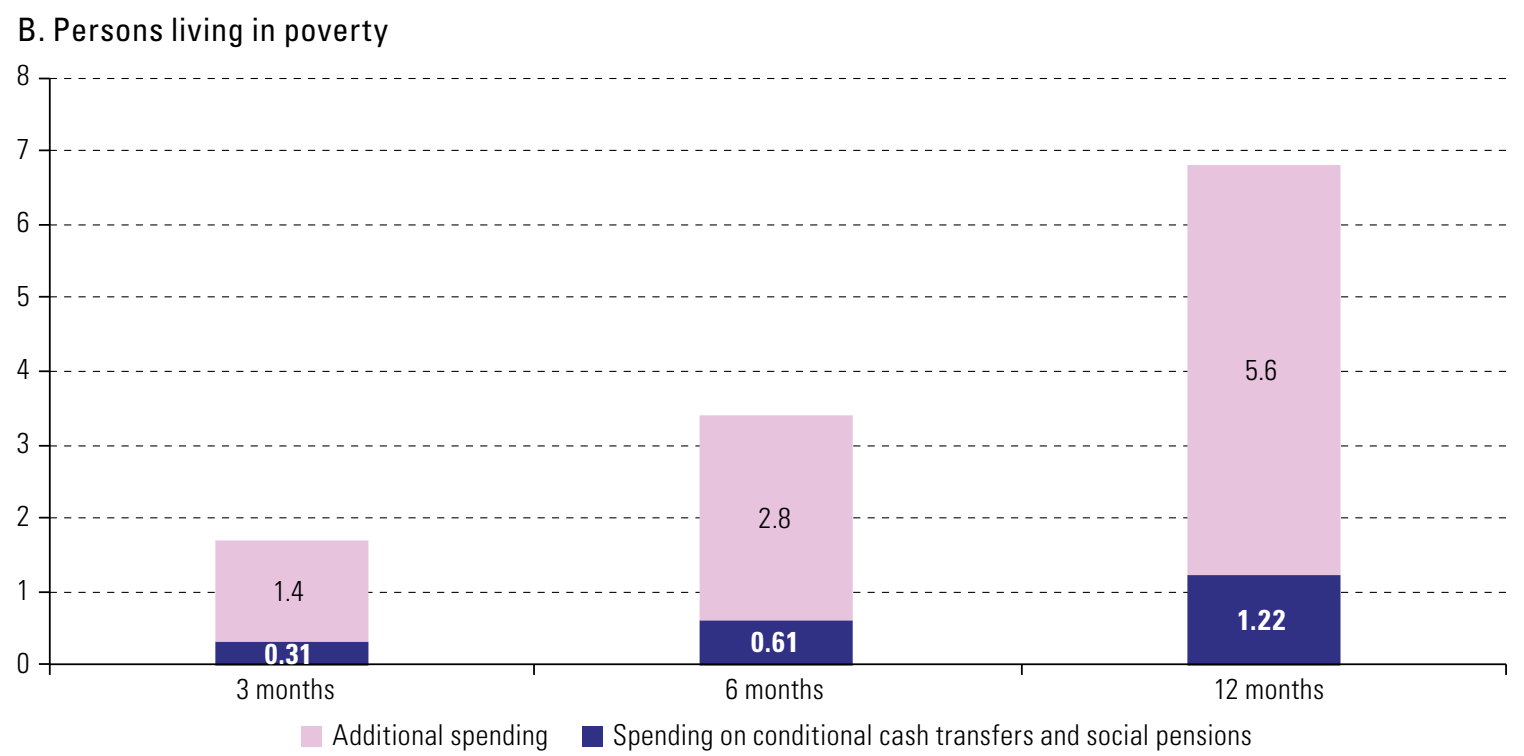

\section{Children and adolescents aged 0-17 years}

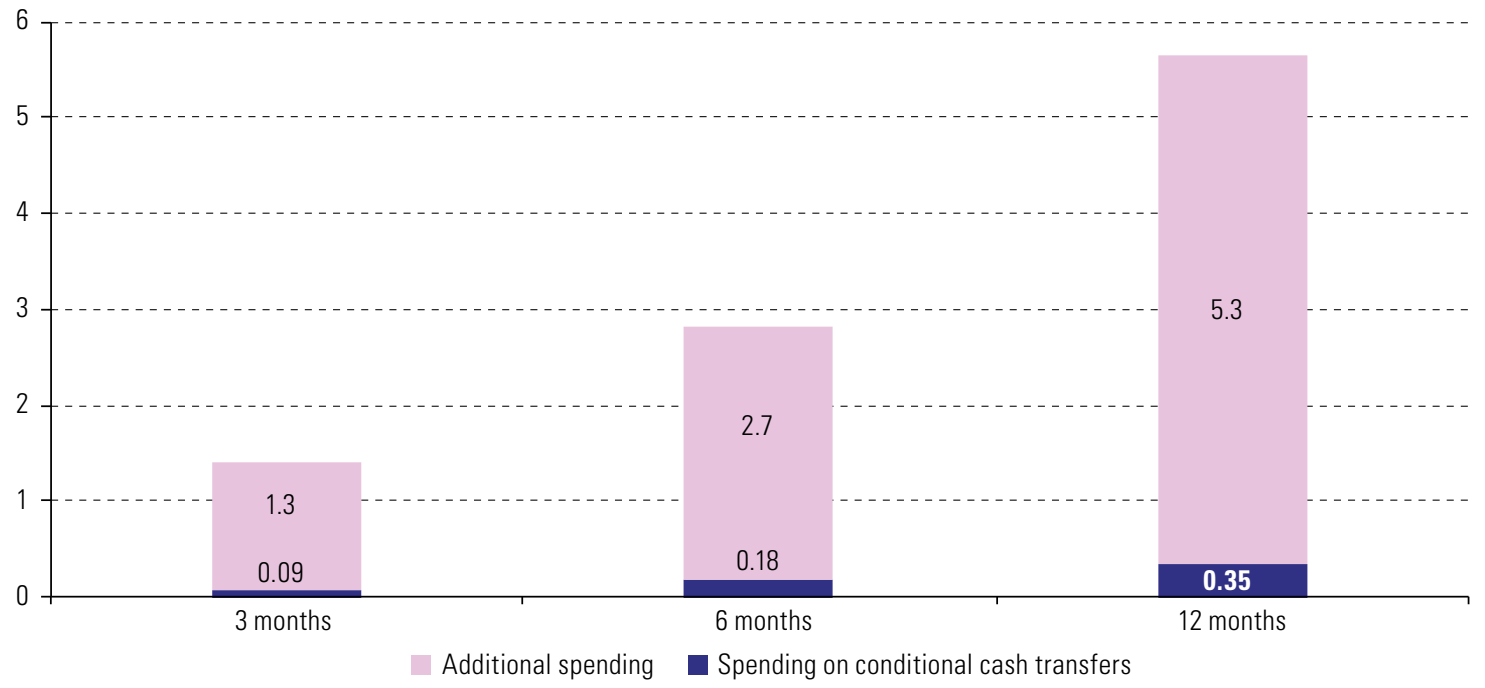

\section{Persons aged 65 years or over}

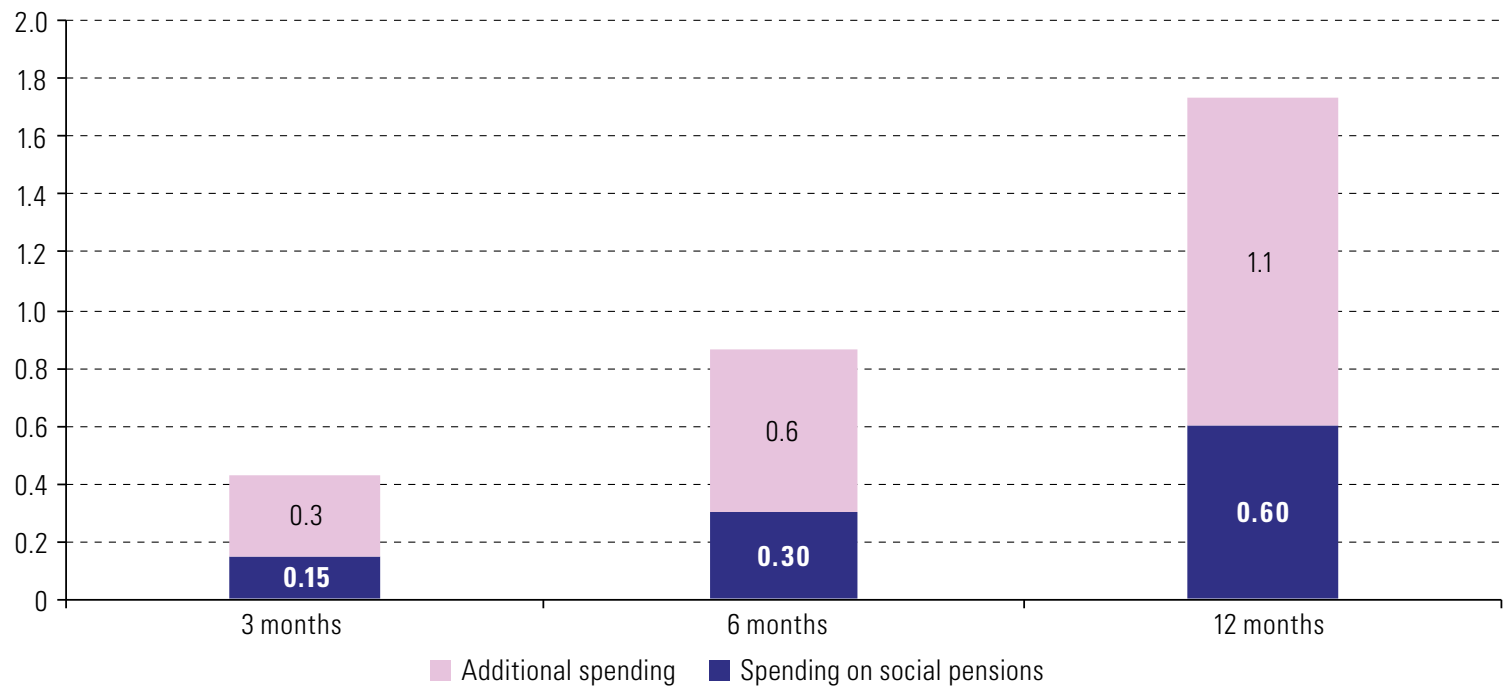

Source: Economic Commission for Latin America and the Caribbean (ECLAC).

a Argentina, Bolivarian Republic of Venezuela, Brazil, Chile, Colombia, Costa Rica, Dominican Republic, Ecuador, El Salvador, Guatemala, Honduras, Mexico, Nicaragua, Panama, Paraguay, Peru, Plurinational State of Bolivia and Uruguay.

bstimate based on a 5.3\% drop in GDP in 2020 and considering a population living in poverty of 214.7 million in the same year. The administrative costs required to make the transfers have not been taken into account. 


\section{E. The challenge is to strengthen the welfare State}

to avoid another lost decade

- Before the pandemic, the social situation in the region had been deteriorating since 2014 in terms of poverty and extreme poverty, with a slowdown in the pace of inequality reduction.

- In view of the major persistent gaps that the pandemic has widened, ECLAC reiterates that it is time to implement universal, redistributive and solidarity-based policies with a rights-based approach, to ensure that no one is left behind.

- From a rights and welfare perspective, emergency responses rooted in social protection must be developed to avoid a serious deterioration in living conditions.

- Social protection responses must link the short-term measures needed to address the most acute manifestations of the crisis to medium- and long-term measures aimed at guaranteeing the exercise of people's rights, by strengthening the welfare State and providing universal social protection. This response should be implemented gradually and sustainable financing mechanisms should be identified.

- In the short term, social protection counteracts the loss of sources of labour income and supports demand by safeguarding household income and consumption, while at the same time facilitating access to health. The crucial actions are establishing a universal income guarantee, especially for informal and precarious workers, as well as ensuring universal access to medical testing and care for all who need it, basic services and housing, adequate food and education for children, adolescents and young people.

- In the medium and long terms, social protection is a central policy for reducing inequalities, making progress towards social inclusion and inclusive growth, and thus for achieving social cohesion. It will be vital to consolidate universal social protection systems, including universal health, that are sensitive to differences and rooted in a rights-based approach, and to develop labour inclusion strategies in the recovery period. These systems make it possible to identify and respond to the impact of the crisis on people's employment and living conditions, and to address the situations faced by different population groups, paying timely attention to informal workers, the most vulnerable age groups, inhabitants of rural and remote areas, indigenous peoples, Afrodescendants, persons with disabilities and migrants.

- Defining a set of universal guarantees for social well-being according to national capacities, in line with the 2030 Agenda for Sustainable Development and the ILO Social Protection Floors Recommendation, 2012 (No. 202), is essential for sustainable development and political stability.

- The Regional Agenda for Inclusive Social Development, adopted in 2019, puts forward lines of action to achieve this objective. It includes proposals for moving towards a universal guarantee of a basic income level and assessing the possibility of gradually incorporating a universal transfer for children and a citizen's basic income into the countries' social protection systems. The Regional Agenda also proposes that social institutions be strengthened to implement high-quality social policies. For the planning, design and implementation of social protection measures, it is important to protect public social spending and to have information, monitoring and evaluation systems for social entitlements, including records of the target or potential target population that are as comprehensive and up-to-date as possible.

- Building the welfare State and universal social protection systems is essential to avoid another lost decade. The international financial crisis of 2008 showed the importance of countercyclical public social spending and social policies aimed at moderating the effects of the crisis on real economies and curbing the rise in unemployment and poverty. By contrast, the debt crisis of the 1980s led to very significant increases in poverty levels. It took 25 years for the region to return to pre-crisis poverty levels. It is important to review these events because the increase in poverty projected by ECLAC for 2020 signifies a 13-year setback for the region (see figure 10). 
Figure 10 | Latin America (18 countries):a per capita GDP and poverty levels, 1980-2020

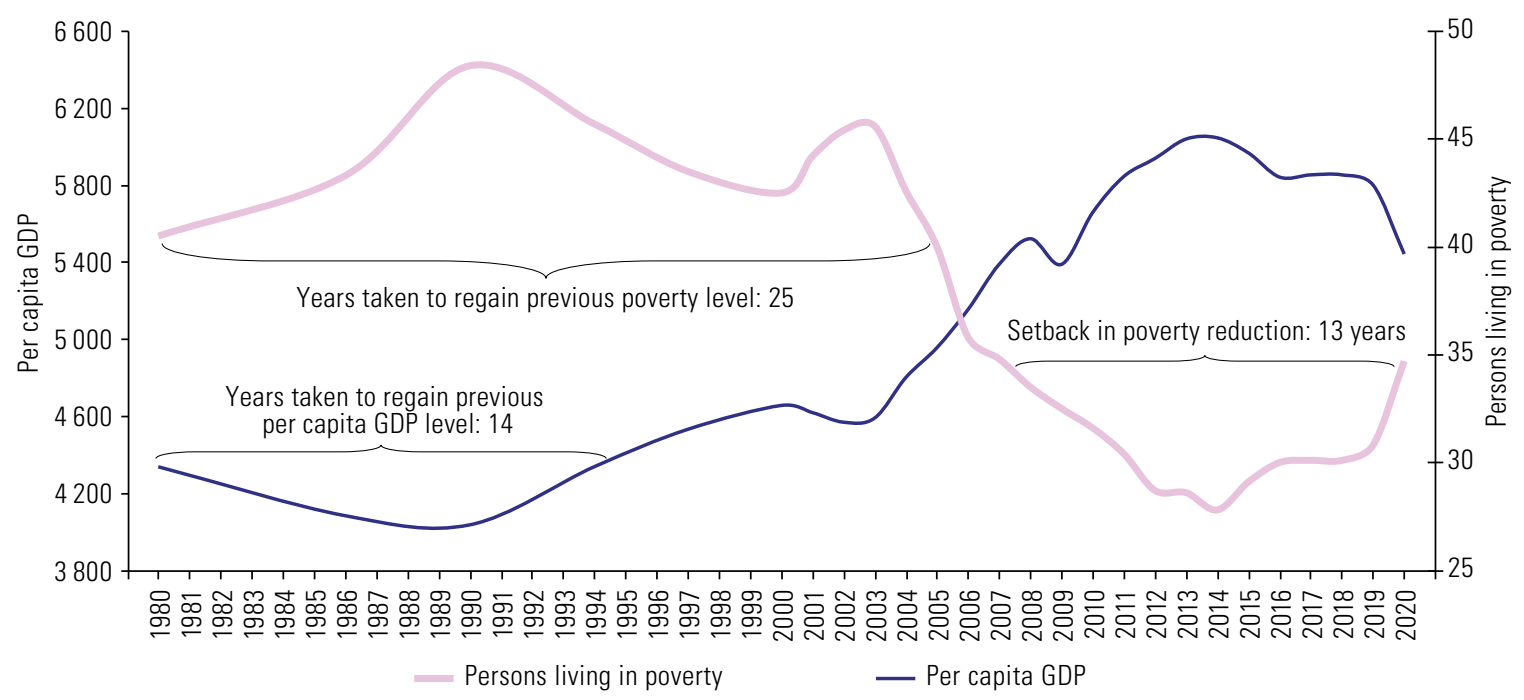

Source: Economic Commission for Latin America and the Caribbean (ECLAC), on the basis of the Household Survey Data Bank (BADEHOG).

a Argentina, Bolivarian Republic of Venezuela, Brazil, Chile, Colombia, Costa Rica, Dominican Republic, Ecuador, El Salvador, Guatemala, Honduras, Mexico, Nicaragua, Panama, Paraguay, Peru, Plurinational State of Bolivia and Uruguay.

${ }^{\mathrm{b}}$ Figures for 2019 are preliminary. Figures for 2020 are projections.

- A central element in building a welfare State is the right to health. Resolving the current fragmentation, hierarchization and commodification of health systems will be one of the lessons of the pandemic. There is also an urgent need for policies of greater scope and depth to address the social determinants of health and, in particular, food and nutritional health requirements.

- The crisis may exacerbate unrest, mistrust and democratic disaffection, posing a major risk to social cohesion. It is urgent to move forward with a social compact focused on well-being and rights at the different stages of the life cycle in order to address the effects of the crisis, with an approach underpinned by collective protection and equality and solidarity-based responses to costs and financing. This will require new fiscal covenants.

- The pandemic has exposed not only the structural limitations of the current economic model, but also the failures and inadequacies of social protection systems and welfare systems in general. In order to protect the living conditions of the whole population, steps must be taken to move towards decent work, promote co-responsibility for care among the State, the market and families, and advance universal access to social protection, by ensuring access to high quality public health systems.

- To overcome the crisis, the development model must be rethought and the economic, social and environmental dimensions of sustainable development consolidated, ensuring that no one is left behind, as called for in the $\mathbf{2 0 3 0}$ Agenda for Sustainable Development. 


\section{Bibliography}

Durán-Valverde, F. and others (2019), "Measuring financing gaps in social protection for achieving SDG target 1.3: global estimates and strategies for developing countries", EES Working Paper, No. 73, Geneva, International Labour Organization (ILO).

ECLAC (Economic Commission for Latin America and the Caribbean) (2020a), "Latin America and the Caribbean and the COVID-19 pandemic: economic and social effects", COVID-19 Special Report, No. 1, Santiago, 3 April.

(2020b), "Measuring the impact of COVID-19 with a view to reactivation", COVID-19 Special Report, No. 2, Santiago, 21 April.

Folha de S. Paulo (2020), "Metade da população poderá ter de receber auxílio, diz estudo" [online] https:// www1.folha.uol.com.br/mercado/2020/05/metade-da-populacao-podera-ter-de-receber-auxilio-dizestudo.shtml.

ILO (International Labour Organization) (2018), Women and Men in the Informal Economy: A Statistical Picture, third edition, Geneva.

Ministry of Health of Brazil (2020), Boletim Epidemiológico Especial COE-COVID19, No. 14, Brasilia, 26 April.

UNESCO (United Nations Educational, Scientific and Cultural Organization) (2020), "COVID-19 educational disruption and response" [online] https://en.unesco.org/covid19/educationresponse.

UNICEF (United Nations Children's Fund) (2020), "COVID-19 pandemic could devastate refugee, migrant and internally displaced populations without urgent international action", 1 April [online] https://www. unicef.org/press-releases/covid-19-pandemic-could-devastate-refugee-migrant-and-internally-displaced. 


\section{Annex}

Table A1 | Latin America and the Caribbean (29 countries): countries that have announced social protection measures for the population living in or vulnerable to poverty to address the effects of the COVID-19 pandemic, by type of measure, as at 24 April 2020

\begin{tabular}{|c|c|c|c|c|c|c|c|}
\hline & $\begin{array}{l}\text { Cash } \\
\text { transfers }\end{array}$ & $\begin{array}{c}\text { Early } \\
\text { disbursement } \\
\text { of existing } \\
\text { cash transfer } \\
\text { programmes }\end{array}$ & $\begin{array}{l}\text { Expansion of } \\
\text { population } \\
\text { coverage } \\
\text { for existing } \\
\text { cash transfer } \\
\text { programmes }\end{array}$ & $\begin{array}{l}\text { Increases } \\
\text { in amounts } \\
\text { allocated } \\
\text { under existing } \\
\text { cash transfer } \\
\text { programmes }\end{array}$ & $\begin{array}{l}\text { New cash } \\
\text { transfers }\end{array}$ & $\begin{array}{l}\text { Provision } \\
\text { of food and } \\
\text { medicine }\end{array}$ & $\begin{array}{l}\text { Basic } \\
\text { services }\end{array}$ \\
\hline \multicolumn{8}{|l|}{ Antigua and Barbuda } \\
\hline \multicolumn{8}{|l|}{ Argentina } \\
\hline \multicolumn{8}{|l|}{ Bahamas } \\
\hline \multicolumn{8}{|l|}{ Barbados } \\
\hline \multicolumn{8}{|l|}{ Belize } \\
\hline \multicolumn{8}{|l|}{$\begin{array}{l}\text { Bolivia (Plurinational } \\
\text { State of) }\end{array}$} \\
\hline \multicolumn{8}{|l|}{ Brazil } \\
\hline \multicolumn{8}{|l|}{ Chile } \\
\hline \multicolumn{8}{|l|}{ Colombia } \\
\hline \multicolumn{8}{|l|}{ Costa Rica } \\
\hline \multicolumn{8}{|l|}{ Cuba } \\
\hline \multicolumn{8}{|l|}{ Dominican Republic } \\
\hline \multicolumn{8}{|l|}{ Ecuador } \\
\hline \multicolumn{8}{|l|}{ El Salvador } \\
\hline \multicolumn{8}{|l|}{ Grenada } \\
\hline \multicolumn{8}{|l|}{ Guatemala } \\
\hline \multicolumn{8}{|l|}{ Guyana } \\
\hline \multicolumn{8}{|l|}{ Haiti } \\
\hline \multicolumn{8}{|l|}{ Honduras } \\
\hline \multicolumn{8}{|l|}{ Jamaica } \\
\hline \multicolumn{8}{|l|}{ Mexico } \\
\hline \multicolumn{8}{|l|}{ Panama } \\
\hline \multicolumn{8}{|l|}{ Paraguay } \\
\hline \multicolumn{8}{|l|}{ Peru } \\
\hline \multicolumn{8}{|l|}{ Saint Lucia } \\
\hline \multicolumn{8}{|l|}{$\begin{array}{l}\text { Saint Vincent } \\
\text { and the Grenadines }\end{array}$} \\
\hline \multicolumn{8}{|l|}{ Trinidad and Tobago } \\
\hline \multicolumn{8}{|l|}{ Uruguay } \\
\hline $\begin{array}{l}\text { Venezuela } \\
\text { (Bolivarian Republic of) }\end{array}$ & & & & & & & \\
\hline
\end{tabular}

Source: Economic Commission for Latin America and the Caribbean (ECLAC).

This Special Report is the third in a series by the Economic Commission for Latin America and the Caribbean (ECLAC) on the evolution and impacts of the COVID-19 pandemic in Latin America and the Caribbean, and will update the economic and social analysis as the relevant information becomes available. The preparation of the Report will be headed by the Executive Secretary of ECLAC, Alicia Bárcena, with the technical support of the Office of the Deputy Executive Secretary, Mario Cimoli, and the substantive divisions responsible for the topics addressed, as well as the subregional headquarters and country offices of ECLAC.

Copyright (C) United Nations, 2020

[ Economic Commission for Latin America and the Caribbean (ECLAC) Comisión Económica para América Latina y el Caribe (CEPAL) www.eclac.org 